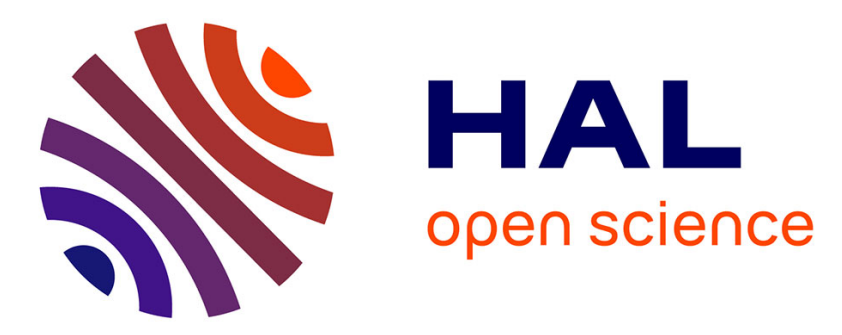

\title{
Tectonics of the Dalrymple Trough and uplift of the Murray Ridge (NW Indian Ocean)
}

Mathieu Rodriguez, Nicolas Chamot-Rooke, Philippe Huchon, Marc Fournier, Siegfried Lallemant, Matthias Delescluse, Sébastien Zaragosi, Nicolas Mouchot

\section{- To cite this version:}

Mathieu Rodriguez, Nicolas Chamot-Rooke, Philippe Huchon, Marc Fournier, Siegfried Lallemant, et al.. Tectonics of the Dalrymple Trough and uplift of the Murray Ridge (NW Indian Ocean). Tectonophysics, 2014, pp.1-49. 10.1016/j.tecto.2014.08.001 . hal-01059557

\section{HAL Id: hal-01059557 https://hal.science/hal-01059557}

Submitted on 1 Sep 2014

HAL is a multi-disciplinary open access archive for the deposit and dissemination of scientific research documents, whether they are published or not. The documents may come from teaching and research institutions in France or abroad, or from public or private research centers.
L'archive ouverte pluridisciplinaire HAL, est destinée au dépôt et à la diffusion de documents scientifiques de niveau recherche, publiés ou non, émanant des établissements d'enseignement et de recherche français ou étrangers, des laboratoires publics ou privés. 
Tectonics of the Dalrymple Trough and uplift of the Murray Ridge (NW Indian Ocean)

Mathieu Rodriguez ${ }^{1 *}$, Nicolas Chamot-Rooke ${ }^{1}$, Philippe Huchon ${ }^{2,3}$, Marc Fournier ${ }^{2,3}$, Siegfried Lallemant $^{4}$, Matthias Delescluse ${ }^{1}$, Sébastien Zaragosi ${ }^{5}$, Nicolas Mouchot $^{6}$

(1) Laboratoire de Géologie de l'Ecole Normale Supérieure, CNRS UMR 8538, 24 rue Lhomond, 75005 Paris, France

(2) Institut des Sciences de la Terre de Paris, UMR 7193, Université Pierre \& Marie Curie, case 129, 4 place Jussieu, 75005 Paris, France

(3) iSTeP, UMR 7193, CNRS, F-75005 Paris, France

(4) Département Géosciences Environnement, Université de Cergy-Pontoise, 5 mail Gay-Lussac, Neuville/Oise, 95031 Cergy-Pontoise, France

(5) EPOC Université de Bordeaux, UMR 5805, avenue des facultés, 33405 Talence, France

(6) Beicip-Franlab, 232 Avenue Napoléon Bonaparte, 92500 Rueil-Malmaison, France

*Corresponding author: rodriguez@geologie.ens.fr

\section{ABSTRACT}

The Dalrymple Trough is a 150-km-long, 30-km-wide basin located at the northern termination of the Owen Fracture Zone (OFZ), which is the present-day active India-Arabia plate boundary. The Dalrymple Trough is closely associated with the Murray Ridge, a complex of prominent bathymetric highs located on its eastern flank. Recent multibeam mapping of the connection between the Dalrymple Trough and the OFZ revealed a horsetail structure, which suggests a close relationship between geological histories of both structures. However, the 3-6 Ma age of initiation of the OFZ contrasts with the commonly accepted Early Miocene emplacement of the Dalrymple Trough. Recent seismic lines document a new tectonic history of the Dalrymple Trough, involving two major episodes of deformation along the India-Arabia plate boundary at 8-10 Ma and $\sim 1.9 \pm 0.9$ Ma. The 8-10 Ma episode is marked by a system of folds linked to the main uplift of the southern Murray Ridge and the first uplift of the northern Murray Ridge. This episode is related to a global plate reorganization event in the Late Miocene, well expressed by intraplate deformation in the Central Indian Ocean. The Dalrymple Trough opened at $\sim 1.9 \pm$ 
0.9 Ma subsequently to the formation of a stepover at the India-Arabia plate boundary, coeval with the regional M-unconformity in the Oman abyssal plain, which marks a structural reorganization of the Makran accretionary wedge, and the last uplift of the northern Murray Ridge.

\section{Introduction}

The Dalrymple Trough consists of a series of basins forming the present-day loose boundary between India and Arabia plates in the Arabian Sea, connecting the pure dextral strike-slip Owen Fracture Zone (OFZ hereafter) to the sinistral Ornach-Nal Fault Zone in Pakistan (Fig. 1; McKenzie and Sclater, 1971; Minshull et al., 1992). The trough is located south of the Makran subduction zone, which absorbs the convergence between the Arabian and Eurasian plates and has produced strong earthquakes in the recent past $\left(\mathrm{M}_{\mathrm{w}}=8.1\right.$ for the 1945 event $)$. The trough is flanked to the east by the Murray Ridge complex, a series of bathymetric highs standing off India and Pakistan.

Seismicity along the entire India-Arabia boundary is scarce, but the strongest magnitude event $\left(M_{w}=5.8\right)$ has been recorded in the Dalrymple Trough (Fig. 2) (Quittmeyer and Kafka, 1984; Gordon and DeMets, 1989; Fournier et al,, 2001). Kinematic models suggest that the present-day opening rate of the Dalrymple Trough does not exceed a few millimeters per year (DeMets et al., 2010; Fournier et al., 2011), with various amounts of transtension.

Multibeam mapping revealed a fault pattern at the southern part of the Dalrymple Trough typical of a horsetail termination (Fig. 1,2) (Fournier et al., 2011; Rodriguez et al., 2011). Few active horsetail terminations have been documented so far in deep-sea environments. These include the northern Andaman Sea at the termination of the Sagaing fault in SE Asia (Pubellier et al., 2005; Cattin et al., 2009; Morley et al., 2013), and the North Aegean Trough at the termination of the North Anatolian fault in the Aegean Sea (Laigle et al., 2000; Papanikolaou et al., 2002; McNeill et al., 2004).

Although the structure of the Dalrymple Trough has been well characterized by previous seismic studies (Edwards et al., 2000, 2008; Gaedicke et al., 2002a,b), the way it connects to the OFZ and how it relates to its tectonic history remain unknown. The main misfit concerns the Pliocene age of the 
OFZ (Fournier et al., 2008a,b; 2011; Rodriguez et al., 2011) and the inferred Early Miocene age of the Dalrymple Trough-Murray Ridge system (Gaedicke et al., 2002a,b; Clift et al., 2001).

Here we present a set of recent seismic reflection data (OWEN-2 cruise) that documents a new stratigraphic framework for the tectonic history of the Dalrymple Trough and the Murray Ridge in close association with structural reorganizations of the India-Arabia plate boundary at $\sim 8-10 \mathrm{Ma}$ and $\sim 1.9 \pm 0.9 \mathrm{Ma}$. The origin of the M-unconformity in the Oman abyssal plain is revised in the light of this new tectonic framework. The first objective of this study is to understand how rifting took place in the Dalrymple Trough, and subsequently evolved into a large and complex stepover basin. The second objective is to unravel the complex, poly-phased history of the Murray Ridge uplift, and identify geodynamic changes that controlled it.

\section{Geological background}

\subsection{Morphology and structure of the Dalrymple Trough and the Murray Ridge}

The Dalrymple Trough is divided into two main segments (Edwards et al., 2000). The southern part of the Dalrymple Trough (between $22-23^{\circ} \mathrm{N}$ ) is a $150-\mathrm{km}$-long, 30-km-wide, $4200-\mathrm{m}$-deep basin, flanked on its eastern side by the $\sim 400$-m deep southern Murray Ridge (Fig. 1, 2). The southern part of the Dalrymple Trough abruptly ends at the Jinnah High at $\sim 23^{\circ} \mathrm{N}$ (Burgath et al., 2002), which is formed by the tilt of the Indus deposits of the Oman abyssal plain (Ellouz-Zimmerman et al., 2007a,b). The Jinnah High marks the transition towards the northern part of the Dalrymple Trough, which is a $\sim 120$ $\mathrm{km}$-long, $\sim 40 \mathrm{~km}$-wide stepover basin. The northern Murray Ridge (between $23^{\circ} \mathrm{N}$ and $23^{\circ} 40^{\prime} \mathrm{N}$ ) forms a normal faulted horst with a more subtle topographic expression than the southern segment (about 1000-m high with respect to the surrounding seafloor, Fig. 1).

The pure strike-slip or transtensive character of a stepover basin depends on the colinearity between the direction of relative motion and that of the strike slip fault (Wu et al., 2009). Because the Dalrymple Trough deviates from the small circle defined by Fournier et al. (2011) (Fig. 2), the structure is considered as transtensive, in agreement with focal mechanisms of earthquakes.

The basement of the Murray Ridge, although never sampled, is interpreted as continental in origin according to seismic refraction data (Edwards et al., 2008). The Dalrymple Trough represents a very 
narrow ocean-continent transition, with abrupt crustal thickness variations from a $\sim 14 \mathrm{~km}$-thick continental crust beneath the Murray Ridge to a 6 km-thick oceanic crust in the Oman abyssal plain (Edwards et al., 2008). A set of volcanic reliefs, namely the Qalhat Seamount and the Little Murray Ridge, are located west of the trough (Fig. 1,2) (Edwards et al., 2000; Fournier et al., 2011).

\subsection{Geological history}

Kinematic and structural studies show that the present-day active OFZ is no older than 3 to $6 \mathrm{Ma}$ (Fournier et al., 2008; 2011; Rodriguez et al., 2011; 2013b). The exact location of the fossil IndiaArabia plate boundary remains debated (Whitmarsh, 1979; Mountain and Prell, 1990; Edwards et al., 2000; Royer et al., 2002). The recent identification of a fracture zone buried under the Indus deposits 5-10 km east of the OFZ (Rodriguez et al., 2014), together with magnetic anomalies reconstructions (Chamot-Rooke et al., 2009), suggest that the plate boundary remained close to the Owen Ridge since at least the beginning of oceanic accretion in the Gulf of Aden in the Early Miocene (Fournier et al., 2010). Buried, abrupt and sharp vertical fault offsets recognized on the eastern side of the Southern Murray Ridge (Edwards et al., 2000) could correspond to the northward prolongation of the fracture zone that used to form the Miocene India-Arabia plate boundary (Fig. 3).

As attested by Paleogene hemipelagites recognized on their top (Shipboard Scientific Party, 1989; Gaedicke et al., 2002a,b), the Owen and Murray Ridges were part of a series of bathymetric highs formed in Paleocene-Early Eocene times (Fig.1, 3) and subsequently rejuvenated during Neogene times. Previous works (Gaedicke et al., 2002b) proposed two phases of uplift of the Murray Ridge related to two coeval phases of subsidence in the Dalrymple Trough, in the Early and the upper Late Miocene. In this framework, two regional angular unconformities, "U" and "M", mark the episodes of uplift and subsidence. Understanding the signification of these unconformities is critical to the understanding of the formation of the Dalrymple Trough and Murray ridge, and how it relates with the history of the OFZ.

\subsection{Regional unconformities in the Arabian Sea}

U-unconformity and the uplift of the Murray Ridge 
The U-unconformity is recognized over the entire Owen Basin and the Oman abyssal plain (Shipboard Scientific Party, 1974; Whitmarsh et al., 1974; 1979; Rodriguez et al., 2014). According to ODP (Ocean Drilling Project) and DSDP (Deep Sea Drilling Project) Sites, the U-unconformity marks a highly diachronous transition between Upper Oligocene-Lower Miocene pelagic chalk and Upper Oligocene-Lower Miocene turbidites coming from the Indus fan. The U-unconformity does not have a tectonic origin, and simply reflects the transition from Oligocene pelagites to Lower Miocene turbidites as the substratum of the Owen Ridge gets progressively buried under the Indus deep-sea fan (Shipboard Scientific Party, 1989; Mountain and Prell, 1990). Therefore, the angular unconformity marking the main uplift of the Murray Ridge recognized by Gaedicke et al. (2002) (picked in blue on Fig. 3) is different from the U-unconformity recognized everywhere in the Owen Basin and the Oman abyssal plain (Rodriguez et al., 2014).

According to an industrial well located in the Indus abyssal plain (Pak-G2-1), the unconformity marking the uplift of the Murray Ridge is 8-10 Ma-old (Fig. 3) (Calvès, 2008). The latter unconformity is formed by 8-9 Ma-old channel-levee system adopting an onlap configuration over a pre-10 Ma-old tilted series of channel-levee systems (Kolla and Coumes, 1987; Calvès, 2008).

This age contrasts with earlier estimations based on a correlation with the age of uplift of the Owen Ridge (Gaedicke et al., 2002), first assessed at 15-20 Ma (Mountain and Prell, 1990). Actually, the East Oman Margin, the Owen Basin, and the Owen Ridge show compressive deformation precisely dated at 8.2-8.8 $\mathrm{Ma}$ at ODP Site 730 (Rodriguez et al., 2014) consistent with the age of the unconformity marking the uplift of the Southern Murray Ridge. An erosive surface at the top of the Owen Ridge, marked by large submarine failures (Rodriguez et al., 2012; 2013), and dated at 8-9 Ma by ties with ODP Site 722, characterizes the younger uplift of the Owen Ridge (Rodriguez et al., 2014).

\section{M-unconformity}

The M-unconformity in the Oman abyssal plain marks both an episode of subsidence in the Dalrymple Trough, and an abrupt tilt of an uniform, 4 km-thick sequence composed of Indus channel-levee systems lying on the subducting plate (Fig. 4) (Gaedicke et al., 2002; Smith et al., 2012). The 
overlying sequence adopts a wedge-shape geometry, with a maximal thickness of $3.5 \mathrm{~km}$ (Smith et al., 2012). It is composed of turbiditic deposits coming from the Makran that onlap the M-unconformity (Fig. 4). The latter is probably coeval with the last stage of uplift of the Murray Ridge, and the opening of the Dalrymple Trough (Gaedicke et al., 2002).

This unconformity has never been drilled, which results in strong uncertainties in its age (Schlüter et al., 2002). First related to a Messinian uplift event in the Zagros Mountain (Ross et al., 1986), it has also been related to the onset of seafloor spreading in the Gulf of Aden (Schlüter et al., 2002), estimated at $13 \mathrm{Ma}$ when these studies were published (Cochran, 1981). The latter age cannot be considered valid anymore according to recent magnetic anomalies studies that document the onset of seafloor spreading in the Gulf of Aden as early as $\sim 20$ Ma (Fournier et al., 2010). Changes in the regime of deformation in the Zagros suggest a 3-7 Ma-old kinematic change related to the ArabiaEurasia collision (Allen et al., 2004; Mouthereau et al., 2012) that may account for the Munconformity, but the existence of this kinematic change remains a matter of debate (Hatzfeld and Molnar, 2010).

\subsection{The Indus deep-sea fan}

Tectonic deformation along the India-Arabia plate-boundary is well recorded by sediments belonging to the Indus turbiditic system. At its thickest part the fan is more than 9-km thick, but its thickness decreases when approaching the Owen-Murray Ridge (Fig. 3c) (Coumes and Kolla, 1984; Clift et al., 2001). It forms a typical mud-rich, "passive margin fan" (sensu Reading and Richards, 1994), with numerous inter-bedded pelagic layers (Shipboard Scientific Party, 1989). Indus Fan sedimentation started during the Middle Eocene as the result of the onset of the India-Eurasia collision and accelerated since the Early Miocene, coincident with a sharp increase in sedimentation rates related to the uplift of the Himalaya and the onset of the Asian monsoon (Clift et al., 2001; Clift and Gaedicke, 2002; Clift et al., 2008). Seismic lines collected in the Indus deep-sea fan document the appearance of well-developed channel-levee complexes since the Middle Miocene (Clift et al., 2001; Calvès, 2008). In the Early Pleistocene, the Indus canyons underwent a southeast migration, leading to a major episode of avulsion and concentration of Indus deposits on the southeastern part of the fan (fossil 
Indus canyons are mapped in Figure 1) (Kolla and Coumes, 1987; Bourget et al., 2013). This migration resulted in dominantly pelagic deposits along the OFZ, allowing a good preservation of the fault scarps morphology on the seafloor (Shipboard Scientific Party, 1974; Rodriguez et al., 2011).

\section{Material and Methods}

The new dataset presented in this study was acquired onboard the French Navy oceanographic vessel Beautemps-Beaupré during the OWEN1 and 2 (2009 and 2012) surveys. Multibeam bathymetry was collected using a Kongsberg-Simrad EM 120 echosounder (Fig. 2), and combined with previously published data acquired during the MARABIE (Bourget et al., 2010) and CHAMAK cruises (EllouzZimmerman et al., 2007a,b). Seismic reflection profiles of the OWEN2 cruise were acquired at 10 knots using two GI air-guns (one 105/105 c.i. and one 45/45 c.i., fired every 10 seconds at 160 bars in harmonic mode, resulting in frequencies ranging from 15 to $120 \mathrm{~Hz}$ ) and a 24-channel, $600 \mathrm{~m}$-long streamer. Seismic profiles have a common mid-point spacing of $6.25 \mathrm{~m}$ and achieved a sub-surface penetration of $\sim 2 \mathrm{~s}$ TWT. The processing consisted in geometry setting, water-velocity normal moveout, stacking, water-velocity F-k domain post-stack time migration, bandpass filtering and automatic gain control. All profiles are displayed with a vertical exaggeration of 8 at the seafloor.

Two-way travel time to seismic reflectors was converted to depth using a P-wave velocity between 1530 and $1730 \mathrm{~m} \cdot \mathrm{s}^{-1}$ for lower and upper bounds. This range of values covers safely the measurements performed in the area in the same pelagic sediments (Shipboard Scientific Party, 1974, 1989). The highest P-wave velocity of $1950 \mathrm{~m} . \mathrm{s}^{-1}$ has been measured in the Pliocene turbidites underneath the pelagic cover (White and Klitgord, 1976; Kolla and Coumes, 1987). The reflectors picked on seismic profiles have been selected based on seismic discontinuities that reflect lithological changes, stratigraphic hiatuses or tectonic deformation. In the following, sedimentary series before the opening of the Dalrymple Trough are referred to as the "substratum" of the Dalrymple Trough, which is employed in the sense of "pre-rift" series, in order to avoid the confusion with the continental basement of the Murray Ridge observed on several profiles.

\section{Stratigraphic framework}




\subsection{Criteria for the identification of sedimentary deposits}

Turbiditic channels are characterized on seismic profiles by a typical lens-like architecture with a concave-up lower boundary, and discontinuous, high amplitude reflection. The associated levees display a wedge shape, with high amplitude, transparent seismic facies. Mass transport deposits display the same chaotic to transparent seismic facies, but their geometry is more irregular. On the other hand, pelagic deposits display well-stratified, continuous and conformable horizons on seismic profiles. It is sometimes difficult to discriminate between turbiditic and pelagic deposits on seismic profiles. Bottom-currents may influence the geometry of pelagic deposits, leading to typical pinchedout, sigmoid geometries referred as contouritic drifts (Faugères et al., 1999). Figure 5 summarizes the main criteria of sedimentary deposits identification.

\subsection{Sedimentation rates}

During turbiditic deposition (Late Miocene-Pliocene), the sedimentation rates ranged between 350 and $600 \mathrm{~m} \mathrm{Ma}^{-1}$ according to estimations at DSDP Site 222 located at the edge of the OFZ (Fig. 1; latitude $\sim 20^{\circ}$ N) (Shipboard Scientific Party, 1974). Turbiditic channels are sealed by a Plio-Pleistocene pelagic drape according to ties with DSDP Site 222 (Shipboard scientific party, 1974; Rodriguez et al., 2011; 2013). Several DSDP and ODP drillings are available along the Owen Ridge (Shipboard Scientific Party, 1974; 1989), but the complete sedimentary sequence of the Murray Ridge has never been drilled down to the basement (Schulz et al., 1998; Ziegler et al., 2010). All average Pleistocene pelagic sedimentation rates estimated at different drilling sites along the Owen-Murray Ridge range between 30 and $55 \mathrm{~m} \mathrm{Ma}^{-1}$ (Shipboard scientific party, 1974, 1989, and core KS07 in Bourget et al., 2013), with the exception of rates of the order of $100 \mathrm{~m} \mathrm{Ma}^{-1}$ (Table 1) estimated from core MD 04873 (Ziegler et al., 2010). However, the nearby core S090-93KL (Schulz et al., 1998) (located only $40 \mathrm{~km}$ away from the core MD 04873) (Fig. 2a) documents rates of about $50 \mathrm{~m} \mathrm{Ma}^{-1}$, which suggests that core MD 04873 has undergone core overpull (Skinner and McCave, 2003). There is consequently little spatial variation of the Pleistocene pelagic sedimentation rates along the Owen Ridge, allowing largescale interpolation of these values in areas exclusively covered by pelagic deposits. However, these 
values cannot be extrapolated in areas where bottom-currents seem to have interacted with pelagic processes, as observed at the edge of the OFZ and the Qalhat Seamount (Fig. 8, 9).

The thickness of the pelagic sediments overlying a reflector marking a geological event can be converted into time using uniform sedimentation rates, therefore providing an age estimate of the geological event. Two major sources of uncertainties are inherent to this approach. First, the estimated pelagic thickness depends on the value of $\mathrm{P}$ wave velocity used to convert two way travel time distance into meters. We estimate different pelagic thicknesses using $\mathrm{P}$ wave velocities ranging between 1550 and $1730 \mathrm{~m} . \mathrm{s}^{-1}$ (table 1). The second source of uncertainty is the regional variability of sedimentation rates, ranging between $30 \mathrm{~m} \cdot \mathrm{Ma}^{-1}$ and $55 \mathrm{~m} \cdot \mathrm{Ma}^{-1}$ (Table 1). The conversion of the pelagic thickness into time is done for the upper and lower estimates of the sedimentation rates, providing the widest range of acceptable age estimates (Table 1). A last source of uncertainties is the measurement of pelagic thickness on seismic profiles, considered in the order of $10 \mathrm{~ms}$ (TWT). Taken all together, the uncertainties related to each age mentioned hereafter are of the order of $1 \mathrm{Myr}$ for the Plio-Pleistocene interval, providing valuable constrains at the time scale of tectonic processes.

\section{Structure of the Dalrymple horsetail}

The Southern part of the Dalrymple Trough is an asymmetric structure comparable to a half-graben oriented $\mathrm{N} 50^{\circ} \mathrm{E}$ bordered by a single normal fault to the southeast, and a complex set of antithetic faults to the west (Fig. 1) (Edwards et al., 2000). The connection between the OFZ and the Dalrymple Trough forms a complex horsetail structure (Fig. 2) composed of several normal faults trending perpendicular to the OFZ, hereafter referred as "transverse faults" (sensu Ben Avraham and ten Brink, 1989). Focal mechanisms indicate a minor strike-slip component in transverse faults motion (Fig. 2). Transverse faults are in the continuation of a dense network of right-stepping, en-échelon faults on the northwestern side of the trough (labelled 1 on Fig. 2). Transverse faults delineate subsiding sub-basins within the trough, whose lengths range between 10 and $20 \mathrm{~km}$ (Fig. 2). The trough forms a syncline basin on seismic lines (Fig. 3, 6) (Edwards et al., 2000; Gaedicke et al., 2002 a,b). Although variable in complexity, this syncline pattern is identified from sub-basin to sub-basin. In detail, the sedimentary sequences that form the syncline basin display a series of angular unconformities (Fig. 6, 7), but the 
syncline itself is isopach, i.e. shows the same thickness throughout. Locally, a dense network of transverse faults offset the syncline basin (Fig. 8). In the area of connection with the trough, the OFZ is oriented $\mathrm{N} 20^{\circ} \mathrm{E}$, and forms a positive flower structure on seismic profiles, expressed by a pressure ridge on the seafloor (Fig. 9, 10). There, contouritic drifts (Fig. 8, 10) mark the transition from turbiditic to pelagic processes possibly related to a major avulsion episode of the Indus deep-sea fan (Kolla and Coumes, 1987; Bourget et al., 2013). Since this transition, contouritic bodies at the edge of the OFZ indicate the presence of a topography driving the bottom-current course.

At the entrance of the trough, the $\mathrm{OFZ}$ is bounded to the east by a set of $\sim \mathrm{N} 40^{\circ} \mathrm{E}$ en-échelon faults (labelled 2 on Fig. 2), which merges northwards with the single normal fault bounding the eastern side of the trough. Both the OFZ and the en-échelon fault system (2) cross cut a buried system of folds observed on the seismic profiles (Fig. 9, 10). Two anticlines separated by a syncline are observed on the eastern side of the OFZ (Fig. 9), whereas a syncline structure is observed on its western side (Fig. 10). The amplitude of the fold-system ranges between 1s (TWT) (Fig. 10) and 2s (TWT) (Fig. 9), indicating bathymetric highs of the order of 700-1500 m before turbiditic covering. The top of one of these anticlines is still forming a $700-\mathrm{m}$ high arcuate relief at the latitude of $21^{\circ} 35^{\prime} \mathrm{N}$ (Fig. $2 ; 6$ ). The tilt of sedimentary layers on the eastern side of the arcuate relief indicates that some compression is still active in this area (Fig. 9) and may represent an analog of the successive unconformities observed in the sequence that was subsequently folded in the Dalrymple Trough (Fig.6). The system of folds shows an isopach deformation at depth, followed by a gentle fanning configuration upward indicating syn-tectonic deposition (Fig. 10). The seismic profile displayed in Fig. 10 highlights a contrast in the deformation pattern on both sides of the OFZ, the syncline structure being observed solely on its western side. The latter results from the right-lateral offset of the fold system, which moved the fold initially located around the latitude of the profile in Fig. 10 to the latitude of the profile in Fig. 9. The southern Murray Ridge follows a $160^{\circ} \mathrm{E}$ trend, and displays an asymmetric shape on seismic sections, with a steeper flank facing the Dalrymple Trough (Fig. 3) (Edwards et al., 2000). The angular unconformity marking the uplift of the southern Murray Ridge (picked in blue) is well identified on its eastern side (Fig. 3) (Edwards et al., 2000; Clift et al., 2001; Gaedicke et al., 2002 a,b) and on its western side (Fig.8). 


\section{Age estimates of the deformation}

Opening of the Dalrymple Trough, Northern Murray Ridge uplift, and M-unconformity

The age of opening of the Dalrymple Trough and of related geological events is estimated by using turbiditic channel-levee systems as morphological markers of the deformation and by regional correlations with ODP Site 722 at the Owen Ridge (Fig. 1).

Previously published multibeam bathymetric data reveal the presence of fossil meandering turbiditic channels on the top of the Murray Ridge (Fig. 2) and the Jinnah High (Ellouz-Zimmermann et al., 2007, Mouchot, 2009; Mouchot et al., 2008, 2010). Turbiditic channels are identified below $4.1 \mathrm{~s}$ (TWT) in the vicinity of the OFZ (Fig. 9, 10) and on the western flank of the Dalrymple Trough (Fig. 6). Perched turbiditic channels are also observed on the eastern flank of the trough (Fig. 6, 8).

All turbiditic channels in the area are blanketed by pelagites that preserved their seafloor expression, but none of them are active anymore in the vicinity of the trough (Deptuck et al., 2003; EllouzZimmermann et al., 2007a,b; Rodriguez et al., 2011). Because of the steep and uneven slopes created by the active thrusts of the Makran wedge, the turbiditic canyons cutting through the wedge do not form any turbiditic channel at their mouth (Bourget et al., 2011). North of the Dalrymple Trough, the Jinnah High acts as a topographic barrier for the turbiditic deposits coming from the Makran (Fig. 4). The origin of the turbiditic sequence observed on both sides of the Dalrymple Trough and below the M-unconformity is thus the Indus deep-sea fan (Gaedicke et al., 2002a,b; Ellouz-Zimmermann et al., $2007 \mathrm{a}, \mathrm{b})$. Therefore, the youngest generation of channel-levee system in the area pre-dates the opening of the Dalrymple Trough and the formation of the M-unconformity, and gives their maximal age. The age of abandonment of the youngest channel-levee is estimated by the thickness of the overlying pelagic cover, converted into time using uniform pelagic sedimentation rates in the area (30-55 $\left.\mathrm{m} \mathrm{Ma}^{-1}\right)$.

Channel-levee systems (labelled A) observed both on the top of the Jinnah High (Ellouz-Zimmerman et al., 2007) and west of the Dalrymple Trough (Fig. 6) are covered by $\sim 0.3 \mathrm{~s}$ (TWT) of pelagic deposits. Channel-levee systems A are therefore $\sim 5.8 \pm 2.2 \mathrm{Ma}$ old (Table 1b). On the other hand, the channel-levee system (labelled B on Figures 6 and 8) observed on the west side of the connection 
between the OFZ and the Dalrymple Trough is covered by a $\sim 0.18 \mathrm{~s}$ TWT-thick pelagic cover, making this channel the youngest in the area. This pelagic thickness indicates that turbiditic sedimentation stopped in the area since at least $3.5 \pm 1.4 \mathrm{Ma}$ (Table $1 \mathrm{~b}$ ). This channel-levee system is dissected by the transverse faults at the entrance of the trough, indicating that it predates this episode of deformation (Fig. 8). The maximal plausible age of the Dalrymple Trough is therefore $3.5 \pm 1.4 \mathrm{Ma}$. Channel-levee systems in the area migrated southwards prior to their deactivation $3.5 \pm 1.4 \mathrm{Ma}$ ago, which indicates that the Oman abyssal plain seafloor was not tilted towards the subduction zone before that time (Mouchot, 2009).

The age of opening of the Dalrymple Trough can be refined by seismic correlations performed on the profile transverse to the trough (Fig. 6,7). The syncline basin forming the trough displays a seismic facies typical of a turbiditic and pelagic layers succession (Fig. 6, 7). It further indicates that the turbiditic sequence identified on both sides of the trough used to be connected before its opening (Fig. 6-8). An unconformable ponded sedimentary sequence, mainly composed of mass transport deposits, seals the syncline basin (Fig. 7). The turbiditic series deformed by the syncline thus corresponds to the substratum of the Dalrymple Trough, the top of which corresponds to the last sedimentary layer deposited before its opening. The uppermost pelagic reflector of the syncline (Fig. 6,7) correlates fairly well with the sedimentary sequence west of the trough, where it is overlain by a $0.1 \mathrm{~s}$ (TWT)thick pelagic cover corresponding to $1.9 \pm 0.9 \mathrm{Myr}$. The most probable age of opening of the Dalrymple Trough is therefore $1.9 \pm 0.9 \mathrm{Ma}$. About 1200 -m of subsidence has been accommodated by the trough since $1.9 \pm 0.9 \mathrm{Ma}$.

On the other hand, the M-unconformity observed on Figure 4 can be correlated up to the Jinnah High. Although indicating a tectonic tilt of the Indus channel-levee systems in the Oman abyssal plain, the dip of the unconformity slightly changes at the approach of the Jinnah High. This change in dip is due to the progressive transition from pelagic to turbiditic deposits as the Makran turbiditic system progressively buries the M-unconformity. The thickness of pelagic deposits covering the Munconformity in the area uncovered by Makran turbidites is $0.1 \mathrm{~s}$ (TWT), which gives an age of about $\sim 1.9 \pm 0.9$ Ma. Since the reflector marking the opening of the Dalrymple Trough (Fig. 6) and the Munconformity are sealed by the same thickness of pelagic sediments, both events are considered 
synchronous. Kolla and Coumes (1987) previously noticed the southeastward shift of the Pleistocene Indus channel-levee systems that may relate to the Pleistocene uplift of the northern Murray Ridge.. Regional correlations of seismic lines show that the pelagic layer overlying the M-unconformity in the vicinity of the Dalrymple Trough is also recognized in the vicinity of the $20^{\circ} \mathrm{N}$ pull-apart basin and at the Southern Owen Ridge (Fig. 11). At the $20^{\circ} \mathrm{N}$ basin, the M-unconformity corresponds to a $2.5 \pm 1$ Ma-old reflector marking the onset of contourite deposition on the western side of the basin (Rodriguez et al., 2013b). There, the onset of contourite deposition may reflect local disturbance of bottom currents following the opening of the basin (Rodriguez et al., 2013b). At the Owen Ridge, the reflector corresponding to the M-unconformity is dated at 2.4 Ma at ODP Site 722 (Discoaster pentaradiatus, sampled at a depth of 74 mbsf, Shipboard Scientific Party, 1989). The age of 2.4 Ma is in the range of ages predicted by the extrapolation of sedimentation rates, and may represent the most likely age of the last structural reorganization of the OFZ expressed by the coeval opening of both the Dalrymple Trough and the $20^{\circ} \mathrm{N}$ Basin and the M-unconformity. Considering a steady India-Arabia motion of $3 \pm 1 \mathrm{~mm} . \mathrm{yr}^{-1}$ (Fournier et al. 2008a,b; 2011), the Dalrymple Trough opened in response to a limited amount of strike-slip motion, in the order of $5-10 \mathrm{~km}$.

\section{Late Miocene Murray Ridge uplift and buried folds}

The use of the distribution of turbiditic channels as a marker of the evolution of the Murray Ridge elevation is more problematic. The profile displayed in Fig. $3 \mathrm{c}$ shows that before its $1.9 \pm 0.9 \mathrm{Ma}$ uplift, the northern Murray Ridge was almost totally buried by Indus turbidites. The paleo-location of the Indus canyon in the northwestern extremity of the Indian margin prior to the Pleistocene (Fig.1, Kolla and Coumes, 1987) implies that turbiditic channels simply bypassed the southern Murray Ridge to flood the Oman abyssal plain. The southern Murray Ridge was thus a prominent high since 8-10 Ma (age of the unconformity marking its uplift; Calvès, 2008), but did not act as a major barrier for the Indus turbidites due to the paleo-location of the canyon (Fig. 1). The northern Murray Ridge, although uplifted around 8-10 Ma (Fig. 4), was less prominent than the Southern Murray Ridge and had been rapidly buried under Indus turbidites. The age of the buried folds identified on Figures 9 and 10 cannot be estimated because of the large range of Late Miocene-Pliocene Indus sedimentation rates (Kolla 
and Coumes, 1987; Clift et al., 2001; Calvès, 2008), but they are probably coeval with the main uplift episode of the southern Murray Ridge at 8-10 Ma. The N-S trend of the arcuate relief at $\sim 21^{\circ} 35^{\circ} \mathrm{N}$ implies a roughly E-W compression at the origin of the Late Miocene deformation.

\section{Discussion}

\subsection{Mode of opening of the south Dalrymple Trough}

The main structural characteristic of the Dalrymple Trough is the numerous transverse faults that form the horsetail structure. Transverse faults are common structures within narrow $(<15-\mathrm{km}$-wide $)$ stepover areas such as the Dead Sea Basin (Kashai and Croker, 1987; Ben Avraham and ten Brink, 1989; Lazar et al., 2006; Smit et al., 2008) or the $20^{\circ} \mathrm{N}$ Basin along the OFZ (Rodriguez et al., 2011, 2013). There, transverse faults form during the opening of the pull-apart basin and were shown to transfer strike slip motion from one main bounding strike-slip segment to the other (Ben Avraham and ten Brink, 1989). Stepovers at the origin of the Dalrymple Trough $(>30 \mathrm{~km})$, the North Aegean Sea $(>40 \mathrm{~km})$, the Andaman Sea $(>100 \mathrm{~km})$ are far much wider, and emplaced in areas of strong crustal thickness variations inherited from previous geological events. Complex structures such as the Jinnah Seamount (Dalrymple), the North Cycladic Detachment Fault (Aegean Sea; Le Pourhiet et al., 2012; Jolivet et al., 2013) or the Alcock Rise (Andaman Sea; Morley, 2013) prevent any connection between bounding strike-slip faults at the extremities of the stepover. In this context, transverse faults cannot result from the transfer of strike-slip motion between bounding strike-slip segments. Analog modeling works (Basile and Brun, 1999) propose that in wide stepover areas, a divergent system composed of normal faults trending perpendicular to the main strike-slip direction emplaces in the first stages of strike-slip motion. As the amount of strike-slip motion increases, the main strike-slip fault connects progressively the transverse normal faults. The first step of these analog models strikingly reproduces the en-échelon fault system (2) observed at the Dalrymple Trough (Fig. 12). However, the full connection of the strike-slip fault with the transverse normal faults implies a large amount of relative motion in the model, which contrasts with the case of the Dalrymple Trough, where only $\sim 5-10 \mathrm{~km}$ of relative motion were accommodated since the first stages of opening $\sim 1.9 \pm 0.9$ Ma. The $\sim 5-10 \mathrm{~km}$ of relative motion at the Dalrymple Trough drastically contrasts with its dimensions (150-km-long, 30- 
$\mathrm{km}$-wide). This raises the question of the relationship between the size of a basin and the amount of finite motion. The formation of a stepover in response to the structural reorganization of the strike-slip fault system isolated a subsiding half graben of dimensions close to the present-day Dalrymple Trough. The connection between the main strike-slip fault and the numerous transverse normal faults may occur in the earliest stages of basin opening, and not progressively as suggested by analog models. The numerous transverse faults individualized several sub-basins, and subsequently accommodated distributed transtension corresponding to the $\sim 5-10 \mathrm{~km}$ of India-Arabia relative motion.

Moreover, the opening of the Dalrymple Trough enhanced the uplift of its flanks, and rejuvenated the topography at the northern Murray Ridge and the westernmost part of the southern Murray Ridge, similar to what is observed along the Dead Sea flanks (Basile and Allemand, 2002). On the other hand, the southern Murray Ridge is outside the area affected by the flexure induced by the Dalrymple Trough, and has probably been little affected by this uplift phase (Fig. 1d).

\subsection{Tectonic history of the Dalrymple Trough-Murray Ridge system}

The results above document at least two major deformation events (Fig. 13) : a first compressional one (8-10 Ma-old) related to the folds observed on the sides of the OFZ (Fig. 9, 10) the main uplift of the southern Murray Ridge, and the first uplift of the Northern Murray Ridge (Fig. 3) (Kolla and Coumes, 1988; Calvès, 2008); and a second one (1.9 \pm 0.9 Ma-old $)$ related to the subsidence of the Dalrymple Trough, the uplift of its flanks (including the major uplift of the northern Murray Ridge), and the formation of the M-unconformity in the Oman abyssal plain (Fig. 4, 6, 7). Compressive deformation was still active in the area since 8-10 Ma. Whether stepover basins inception is coeval with the inception of the OFZ is difficult to assess, as some stepover basins were shown to develop a few million years after the initiation of the San Andreas Fault (e.g. Wakabayashi, 2007) and the Levant Fault (Garfunkel and Ben Avraham, 2001). The alternative involves a third, intermediate episode, in which the OFZ emplaced at $\sim 6 \mathrm{Ma}$, and then underwent opening of stepover basins at $1.9 \pm 0.9 \mathrm{Ma}$. However, the location of the plate boundary for the 3-6 Ma time span is unknown. It is even possible than India and Arabia were temporary coupled during this time span, both Carlsberg and Sheba ridges 
showing similar half spreading rates at $\sim 3 \mathrm{~cm}_{\mathrm{yr}}{ }^{-1}$ (Merkouriev and DeMets, 2006; Fournier et al., 2010). This framework, summarized in Figure 13, contrasts with the two stages history (in the Early and the Late Miocene) previously assessed (Gaedicke et al., 2002), and implies a new geodynamic interpretative scheme of the Dalrymple Trough-Murray Ridge system.

\section{Origin of the 8-10 Ma-old compressional episode of deformation}

The uplift of the Southern Murray Ridge is coeval with widespread deformation in the Owen Basin (Rodriguez et al., 2014) and the ending of seafloor spreading rates deceleration at 8-11 Ma recorded by magnetic anomalies at the Carlsberg Ridge (Mercuriev and DeMets, 2006). The Late Miocene deformation in the Arabian sea coincides in time with a Late Miocene global plate reorganization event, which is expressed in the Indian Ocean by the separation of Somalia from Africa (DeMets et al., 2005; Mercuriev and DeMets, 2006) and intra-plate deformation in the Central Indian Ocean, separating India from Australia (Weissel et al., 1980; Wiens et al., 1985; Bull and Scrutton, 1990; 1992; Chamot-Rooke et al., 1993; Henstock and Minshull, 2004; Delescluse et al., 2008; Krishna et al., 2009; Copley et al., 2010). The increase in stress applied by the Miocene growth of the Himalayas on India's plate boundaries has been tentatively proposed as the driver for this plate reorganization event (Molnar et al., 1993; Molnar and Stock, 2009; Bull et al., 2010). However, the present-day deformation west of the Chagos-Laccadive is extension rather than compression (Henstock and Minshull, 2004). The compressive deformation at the India-Arabia plate boundary probably results from complex tectonic interactions between both plates.

\section{Origin of the $1.9 \pm 0.9$ Ma-old transtensive episode of deformation}

The M-unconformity records both the tilt of Indus series in front of the Makran and the opening of the Dalrymple Trough, suggesting a common origin. This episode of deformation induced a second uplift of the northern Murray Ridge. The opening of the Dalrymple Trough isolated the Makran from Indus sediments, the only remaining source of sediments being the Makran turbiditic system. The younger age of the M-unconformity implies that the erosion rates of the Makran accretionary wedge have been

strong during the Pleistocene, probably in the same order as current rates ( $>2 \mathrm{~mm} . \mathrm{yr}^{-1}$, Bourget et al., 
2011). Sedimentation rates control the temperature at the deformation front, high sedimentation rates favoring shallow seismogenic rupture along megathrusts (Smith et al., 2012; 2013). This Late Pliocene transition in the sedimentation regime may have affected both the structural organization of the wedge and its seismogenic potential.

The reflector marking the opening of the Dalrymple Trough and the $20^{\circ} \mathrm{N}$ Basin being the same (Fig. 11), the reorganization of the OFZ between $20^{\circ} \mathrm{N}$ and $24^{\circ} \mathrm{N}$ may be coeval with the last structural reorganization of the Makran accretionary wedge marked by the M-unconformity.

\section{Conclusions and perspectives}

This study documents a Late Miocene compressive episode along the India-Arabia plate boundary expressed by a complex set of folds at the connection between the OFZ and the Dalrymple Trough.

The U-unconformity is not recognized at the Murray Ridge, whose uplift is recorded by an angular unconformity dated at 8-10 Ma (Calvès, 2008). A Late Miocene compressive episode of deformation is recognized throughout the Owen Basin (Rodriguez et al., 2014) and is linked to a Late Miocene global plate reorganization event.

This study also shows the formation of a stepover area $\sim 1.9 \pm 0.9 \mathrm{Ma}$ at the origin of both the Dalrymple Trough and the second uplift of the Northern Murray Ridge. This age is significantly younger than the Miocene age previously proposed (Gaedicke et al., 2002) and in better agreement with the recent age of the OFZ, which shows no structure older than $3 \mathrm{Ma}$ along strike (Rodriguez et al., 2011; 2013). This younger age also implies that large stepover basins (150-km-long) can develop with limited amount of strike-slip motion (5-10 km). Moreover, the M-unconformity is not coeval with the structural reorganization that affected the Makran wedge during Tortonian (McCall, 1997; Burg et al., 2008; Smit et al., 2010), and marks a younger episode of structural reorganization 1.9 $\pm 0.9 \mathrm{Ma}$. The reassessment of the tectonic framework of the Dalrymple Trough and the Murray Ridge points out interesting regional perspectives for the Indus turbiditic system and the Makran accretionary wedge. The last structural reorganization marked by the M-unconformity is roughly coeval with the opening of the Dead Sea Basin along the Levant Fault (TenBrink et al., 1989). Whether coeval deformation events along both strike-slip boundaries of the Arabian plate reflect a poorly constrained Late 
Pliocene-Early Pleistocene kinematic change remains enigmatic (Allen et al., 2004; Smit et al., 2009, Schattner, 2010). Considering the regional correlation with ODP Site 722, the last structural reorganization marked by the M-unconformity is likely to be synchronous with a major monsoon intensification over Asia around 2.4 Ma (Bloemendal and DeMenocal, 1989; An et al., 2001; Wang et al., 2005; Huang et al., 2007), affecting the Makran and the Himalayan foreland. The critical Coulomb wedge theory and geological studies (Berger et al., 2008; Whipple, 2009; Malavieille, 2010; Iaffaldano et al., 2011) suggest that major climate changes can affect the wedge taper at a regional scale, and induce widespread structural reorganization. Deep-sea drillings would be useful to decipher the precise timing of the deformation in the area and confirms the link with monsoon intensity. Second, the uplift of the northern Murray Ridge since $\sim 1.9 \pm 0.9$ Ma might account for the Pleistocene southwestward migration of the Indus canyon on the Indian Margin (Kolla and Coumes, 1987). A precise dating of the episodes of migration of the canyon, together with reconstructions of the evolution of the topography fossilized by channel-levee systems, would highlight the complex interaction between tectonic and sedimentary processes (see similar examples in Mulder et al., 2012).

\section{Acknowledgements}

We thank the SHOM and GENAVIR team for their help in data acquisition. Processing of the OWEN2 dataset was carried out using the Geocluster 5000 software from CGGVeritas. We thank P. Dubernet and N. Bacha for technical assistance, and L. Le Pourhiet for scientific discussions about horsetail terminations. Tim Minshull and Lisa McNeill provided very detailed and constructive comments that greatly helped us to improve this article. This study was supported by SHOM, IFREMER, INSUCNRS, and CEA (LRC Yves-Rocard).

\section{Figure captions :}

Figure 1 :a) Shaded-relief bathymetry of the Arabian sea and surrounding topography, from Becker et al., 2009 and Fournier et al., 2011. LMR : Little Murray Ridge. Red stars: drill sites b) Simplified 
cross section of the Oman abyssal plain, modified from White and Klitgord (1976) (see a) for location). c) and d) : topographic profiles running transverse to the northern and southern Murray Ridge. Inset shows the simplified geodynamic framework of the Arabian Sea. AOC: Aden-OwenCarlsberg triple junction.

Figure 2 : Multibeam bathymetric map of the Dalrymple Trough (a), and interpretative morphostructural scheme (b), with local crustal seismicity since 1973 (focal depth $<50 \mathrm{~km}$, magnitude Mw > 2) from available databases. The small circle about the closure-enforced MORVEL ArabiaIndia rotation pole (dark blue dashed line; DeMets et al., 2010) is parallel to the trend of the OFZ at the entrance of the trough, whereas the small circle determined from the active trace of the OFZ (light blue dashed line, Fournier et al., 2011) is parallel to the trace of the OFZ up to $21^{\circ} 30^{\circ} \mathrm{N}$ and to the enéchelon fault system labeled "2". Location of seismic profiles is indicated by black dashed lines. Insets show close bathymetric views of the turbiditic channels observed in the area, labeled A and B according to their age of activity (A : older channel, $5.8 \pm 2.2 \mathrm{Ma}$, B : younger channel, $3.5 \pm 1.4 \mathrm{Ma}$ ). Yellow stars: drill sites.

Figure 3 : a-b) Line drawing of previously published seismic profiles and c) seismic line crossing in the Dalrymple Trough-Murray Ridge area(see the inset in the upper right hand corner for location and Fig. 2). a) Line drawing of a profile crossing the southern Murray Ridge, from Gaedicke et al., 2002b. The U-unconformity is not recognized on the eastern side of the Dalrymple Trough and in the vicinity of the Murray Ridge; b) Line drawing of a profile crossing the Dalrymple Trough and the southern Murray Ridge, modified after Edwards et al., 2000. A potential fracture zone offset is identified on the eastern flank of the Murray Ridge; c) Profile modified from Kolla and Coumes (1987) showing an angular unconformity on the eastern side of the Murray Ridge. The angular unconformity was dated at 8-10 Ma by calibration with an industrial drilling located in the Indus deep-sea fan (Pak-G2-1; Calvès, 2008). CLS= Channel-Levee Systems. 
Figure 4 : Seismic profile from the Chamak cruise (Ellouz-Zimmerman et al., 2007; Mouchot, 2009) crossing the Jinnah High, showing the M-unconformity (see figure 2 for location).a) close view of the M-unconformity in the area of the Jinnah High; b) Seismic profile showing the M-unconformity and c) its line drawing. CLS = channel-levee system.

Figure 5 : Synthesis of the seismic facies of the main sedimentary deposits observed in the study area.

Figure 6 : a) Bathymetry of the connection between the Owen Fracture Zone (OFZ) and the Dalrymple Trough, showing en-échelon faults connecting transverse normal faults within the trough. b) Seismic profile transverse to the Dalrymple Trough (see Fig. 2 and 6a for location) and c) interpretation. MTD = mass transport deposits. $\mathrm{CLS}=$ channel-levee system.

Figure 7 : Close view of the seismic profile displayed in fig. 6, showing the stratigraphic correlation of the last deformed layer within the trough with its western border. The last deformed layer within the trough coincides with the $\mathrm{M}$ unconformity in the Oman Abyssal Plain. Close views of the profile highlight the similar seismic sequence within and outside the Dalrymple Trough prior its opening.

Figure 8 : a) seismic profile crossing the transverse fault system and b) the interpretation.

Figure 9 : a) seismic profile crossing the Owen fracture Zone at the entrance of the Dalrymple Trough (see Fig. 2 and 6 for location) and b) the interpretation.

Figure 10 : a)Seismic profile crossing the Owen Fracture Zone (OFZ) and the en-échelon fault system 2 (see Fig. 2 and 6 for location) and b) its interpretation. c) shows a bathymetric view of the enéchelon fault system 2, with a particular emphasis over its relationship with fossil Indus turbiditic channels. 
Figure 11 : Regional correlation of seismic facies at the edges of the Dalrymple Trough, the $20^{\circ} \mathrm{N}$ Basin (Rodriguez et al., 2013) and the Owen Ridge (Shipboard Scientific Party, 1989; Rodriguez et al., 2014).

Figure 12 : Simplified structural sketchmap of the Dalrymple Trough and comparison with results from analog modeling experiments from Basile and Brun (1999).

Figure 13 : Sketches of the geological history of the Dalrymple Trough and the Murray Ridge. OFZ : Owen Fracture Zone, PB : Plate-Boundary. Stage A : A Late Miocene episode (8-10 Ma) of compression along the India-Arabia plate boundary triggered the main uplift of the Murray Ridge. The plate boundary was probably located on the eastern side of the Murray Ridge according to sharp offsets of the basement observed on previously collected seismic lines (see Fig. 3). Stage B : This intermediate stage considers the alternative in which the opening of the Dalrymple Trough is not coeval with the inception of the OFZ. Since the emplacement of the OFZ between 3-6 Ma, Late Miocene folds were offset dextrally and progressively buried under Indus turbidites. Stage C: The Dalrymple Trough opened ( 2-3 Ma), and provoked a new episode of uplift of the northern Murray Ridge. It is related to the formation of the M-unconformity in the Oman abyssal plain. At the same time, the Indus canyon began its migration towards the south-east.

Table 1 : a) Range of sedimentation rates calculated at different drilling sites in the Arabian Sea (see Fig. 1 for location). b) Age estimations of the different markers used in this study, from conversion of pelagic sediment thicknesses into time. Different values of sedimentation rates calculated at the different drilling/coring sites available, as well as different P-wave velocities, are used for the conversion of the pelagic thickness into time.

\section{References}


Allen, M., Jackson, J., Walker, R., 2004. Late Cenozoic reorganization of the Arabia-Eurasia collision and the comparison of short term and long term deformation rates. Tectonics 23, TC2008, doi:10.1029/2003TC001530.

An, Z., Kutzbach, J.E., Prell, W.L., Porter, S.C., 2001.Evolution of Asian monsoons and phased uplift of the Himalaya-Tibetan plateau since Late Miocene times. Nature 411, 62-66.

Basile, C., Brun, J.P., 1999. Transtensional faulting patterns ranging from pull-apart basins to transform continental margins: an experimental investigation. Journal of Structural Geology 21, $23-37$.

Basile, C., Allemand, P., 2002. Erosion and flexural uplift along transform faults. Geophysical Journal International $151,646-653$.

Becker, J.J., Sandwell, D.T., Smith, W.H.F., Braud, J., Blinder, B., Depner, J., Fabre, D., Factor, J., Ingalls, S., Kim, S. H., Ladner, R., Marks, K., Nelson, S., Pharaoh, A., Trimmer, R., VonRosenberg, J., Wallace, G., Weatherall, P., 2009. Global bathymetry and elevation data at 30 arc second resolution: SRTM30PLUS. Mar. Geod. 32, 355-371. http://dx.doi.org/10.1080/01490410903297766.

Ben Avraham, Z., Ten Brink, U. S., 1989. Transverse faults and segmentation of basins within the Dead Sea Rift. Journal of African Earth Science 8, 603-616.

Berger, A., Gulick, S.P.S., Spolita, J. A., Upton, P., Jaeger, J. M., Chapman, J. B., Worthington, L. A., Pavlis, T. L., Ridgway, K. D., Willems, B. A., McAleer, R. J., 2008. Quaternary tectonic response to intensified glacial erosion in an orogenic wedge. Nature geoscience 1, 793-799, doi:10.1038/ngeo334

Bourget, J., Zaragosi, S., Ellouz-Zimmermann, N., Ducassou, E., Prins, M.A., Garlan, T., Lanfumey, V., Rouillard, P., Schneider, J-L., 2010. Highstand vs. lowstand turbidite system growth in the Makran active margin: imprints of high-frequency external controls on sediment delivery mechanisms to deep water systems. Marine Geology 274, 187-208

Bourget, J., Zaragosi, S., Ellouz-Zimermann, N., Mouchot, N., Garlan, T., Schneider, J.-L., Lanfumey, V., Lallemant, S., 2011.Turbidite system architecture and sedimentary processes along 
topographically complex slopes: The Makran convergent margin. Sedimentology 58, 376-406, doi:10.1111/j.1365-3091.2010.01168.x

Bourget, J., Zaragosi, S., Rodriguez, M., Fournier, M., Garlan, T., Chamot-Rooke, N., 2013. Late Quaternary megaturbidites of the Indus Fan: Origin and stratigraphic significance. Marine Geology 336, 10-23, http://dx.doi.org/10.1016/j.margeo.2012.11.011.

Bull, J. M., Scrutton, R. A., 1990. Fault reactivation in the central Indian Ocean and the rheology of oceanic lithosphere. Nature 344, 855-858.

Bull, J. M., Scrutton, R. A., 1992. Seismic reflection images of intraplate deformation, central Indian Ocean, and their tectonic significance. J. Geol. Soc. London 149, 955-966.

Bull, J. M., DeMets, C., Krishna, K. S., Sanderson, D. J., Merkouriev, S., 2010. Reconciling plate kinematic and seismic estimates of lithospheric convergence in the central Indian Ocean. Geology 38, 307-310, doi: 10.1130/G30521.1

Burg, J.P., Bernoulli, D., Smit, J., Dolati, A., Bahroudi, A., 2008. A giant catastrophic mud-and-debris flow in the Miocene Makran. Terra Nova 20, 188-193, doi: 10.1111/j.1365-3121.2008.00804.x

Burgath, K. P., Von Rad, U., Van der Linden, W., Block, M., Ali Khan, A., Roeser, H. A., Weiss, W., 2002. Basalt and peridotites from Murray Ridge: are they of supra-subduction origin? in The Tectonic and Climatic Evolution of the Arabian Sea Region, edited by P. D. Clift et al., Geological Society Special Publication, 195, 117-135

Cattin, R., Chamot-Rooke, N., Pubellier, M., Rabaute, A., Delescluse, M., Vigny, C., Fleitout, L., Dubernet, P., 2009. Stress change and effective friction coefficient along the Sumatra-AndamanSagaing fault system after the 26 December $2004(\mathrm{Mw}=9.2)$ and the 28 March $2005(\mathrm{Mw}=8.7)$ earthquakes. Geochemistry, Geophysics, Geosystems 10, doi:10.1029/2008GC002167.

Calvès, G., 2008. Tectonostratigraphic and climatic record of the NE Arabian Sea, Ph.D. thesis, 305 pp., Univ. of Aberdeen, Aberdeen U. K.

Chamot-Rooke, N., Jestin, F., DeVoogd, B., 1993. Intraplate shortening in the central Indian-ocean determined from a 2100-km-long north-south deep seismic-reflection profile. Geology 21, 10431046. 
Chamot-Rooke, N., Fournier, M., Scientific Team of AOC and OWEN cruises, 2009. Tracking Arabia-India motion from Miocene to Present. American Geophysical Union, Fall Meeting 2009.

Clift, P. D., Shimizu, N., Layne, G. D., Blusztain, J. S., Gaedicke, C., Schluter, H.-U., Clark, M. K., Amjad, S., 2001. Development of the Indus Fan and its significance for the erosionalhistory of the Western Himalaya and Karakoram. Geological Society of America Bulletin 113(8), 1039-1051.

Clift, P. D., Gaedicke, C, 2002. Accelerated mass flux to the Arabian Sea during the middle to late Miocene. Geology 30, 207-210. doi:10.1130/0091-13

Clift, P. D., Hodges, K. V., Heslop, D., Hannigan, R., Van Long, H., Calvès, G., 2008. Correlation of Himalayan exhumation rates and Asian monsoon intensity. Nat. Geosci. 1, 875-880, doi:10.1038/ngeo351

Cochran, J. R., 1981. The Gulf of Aden: structure and evolution of a young ocean basin and continental margin. Journal of Geophysical Research 86, 263-287.

Copley, A., Avouac, J-P., Royer, J-Y., 2010. India-Asia collision and the Cenozoic slowdown of the Indian plate: implications for the forces driving plate motions. J. Geophys. Res. 115, B03410, doi:10.1029/2009JB006634

Coumes, F., Kolla, V., 1984. Indus Fan: seismic structure, channel migration and sediment thickness in the upper fan. in: Haq, B.U., J.D., M. (Eds.), Marine Geology and Oceanography of Arabian Sea and coastal Pakistan. Van Nostrand Reinhold Comp., New York, pp. 101-110.

Delescluse, M., Chamot-Rooke, N., 2007. Instantaneous deformation and kinematics of the IndiaAustralia Plate. Geophysical Journal International 168, 818-842, doi: 10.1111/j.1365246X.2006.03181.x

Delescluse, M., Montési, L. G. J, Chamot-Rooke, N., 2008. Fault reactivation and selective abandonment in the oceanic lithosphere. Geophysical Research Letters 35, L16312 doi:10.1029/2008GL035066

DeMets, C., Gordon, R., Royer, J-Y., 2005. Motion between the Indian, Capricorn and Somalian plates since $20 \mathrm{Ma}$ : implications for the timing and magnitude of distributed lithospheric deformation in the equatorial Indian Ocean. Geophysical Journal International 161, 445-468, doi: 10.1111/j.1365-246X.2005.02598.X 
DeMets, C., Gordon, R.G., Argus, D.F., Stein, S., 1990. Current plate motions. Geophysical Journal International 101, 425-478.

DeMets, C., Gordon, R.G., Argus, D.F., Stein S., 1994. Effect of recent revisions of the geomagnetic reversal time scale on estimates of current plate motions. Geophysical Research Letters 21, 21912194.

DeMets C., Gordon R. G., Argus, D.F., 2010. Geologically current plate motions, Geophysical Journal International 181, 1-80. doi: 10.1111/j.1365-246X.2009.04491.x.

Deptuck, M. E., Steffens, G. S., Barton, M., Pirmez, C., 2003. Architecture and evolution of upper fan channel-belts on the Niger Delata slope and in the Arabian Sea. Marine and Petroleum Geology 20, 649-676.

Edwards R.A., Minshull, T. A., White, R. S., 2000. Extension across the Indian-Arabian plate boundary: the Murray Ridge. Geophysical Journal International 142, 461-477.

Edwards, R. A., Minshull, T. A., Flueh, E. R., Kopp, C., 2008. Dalrymple Trough: An active obliqueslip ocean-continent boundary in the northwest Indian Ocean. Earth and Planetary Science Letters $272,437-445$.

Ellouz Zimmermann, N., Deville, E., Müller, C., Lallemant, S., Subhani, A. B., Tabreez, A. R., 2007a. Impact of sedimentation on convergent margin tectonics : example of the Makran Accretionary prism (Pakistan). Thrust Belts and Foreland Basins: From Fold Kinematics to Hydrocarbon Systems, edited by O. L. Lacombe et al., pp. 327-350, Springer, Berlin.

Ellouz-Zimmermann, N. et al., 2007b. Offshore frontal part of the Makranaccretionary prism (Pakistan) the Chamak Survey in Thrust Belts and Foreland Basins: From Fold Kinematics to Hydrocarbon Systems, edited by O. L. Lacombe et al., pp. 349-364, Springer, Berlin.

Faugères, J.C., Stow, D.A.V., Imbert P., Viana, A. 1999. Seismic features diagnostic of contourite drifts, Marine Geology 162, 1-38.

Ford, M., Rohais, S., Williams, E. A., Bourlange, S., Jousselin, D., Backert, N., Malartre, F., 2013. Tectono-sedimentary evolution of the western Corinth rift (Central Greece). Basin Research 25, 325, doi : 10.1111/j.1365-2117.2012.00550.x 
Fournier, M., Patriat, P., Leroy, S., 2001. Reappraisal of the Arabia-India-Somalia triple junction kinematics. Earth and Planetary Science Letters 189, 103-114.

Fournier, M., Chamot-Rooke, N., Petit, C., Fabbri, O., Huchon, P., Maillot, B., Lepvrier, C., 2008a. In-situ evidence for dextral active motion at the Arabia-India plate boundary. Nature Geoscience 1, 54-58 http://dx.doi.org/10.1038/ngeo.2007.24.

Fournier, M., Petit, C., Chamot-Rooke, N., Fabbri, O., Huchon, P., Maillot, B., Lepvrier, C., 2008b. Do ridge-ridge-fault triple junctions exist on Earth? Evidence from the Aden-Owen-Carlsberg junction in the NW Indian Ocean. Basin Research 20, 575-590 http://dx.doi.org/10.1111/j.13652117.2008.00356.x.

Fournier, M., Chamot-Rooke, N., Petit, C., Huchon, P., Al-Kathiri, A., Audin, L., Beslier, M.-O., d'Acremont, E., Fabbri, O., Fleury, J.-M., Khanbari, K., Lepvrier, C., Leroy, S., Maillot, B., Merkouriev, S., 2010. Arabia-Somalia plate kinematics, evolution of the Aden-Owen-Carlsberg triple junction, and opening of the Gulf of Aden. Journal of Geophysical Research 115, B04102 http://dx.doi.org/10.1029/2008JB006257.

Fournier, M., Chamot-Rooke, N., Rodriguez, M., Huchon, P., Petit, C., Beslier, M.-O., Zaragosi, S., 2011. Owen Fracture Zone: the Arabia-India plate boundary unveiled. Earth and Planetary Science Letters 302, 247-252 http://dx.doi.org/10.1016/j.eps1.2010.12.027.

Gordon, R.G., DeMets, C., 1989. Present-day motion along the Owen fracture zone and Dalrymple trough in the Arabian Sea. Journal of Geophysical Research 94, 5560-5570.

Gaedicke, C., Schlüter, H. U., Roeser, H. A., Prexl, A., Schreckenberger, B., Meyer, H., Reichert, C., Clift, P., Amjad, S., 2002a. Origin of the northern Indus Fan and Murray Ridge, Northern Arabian Sea: interpretation from seismic and magnetic imaging. Tectonophysics, 355,127-143, http://dx.doi.org/10.1016/S0040-1951(02)00137-3

Gaedicke, C., Prexl, A., Schlüter, H.-U., Roeser, H., Clift, P., 2002b. Seismic stratigraphy and correlation of major regional unconformities in the northern Arabina Sea. In: The Tectonic and Climatic Evolution of the Arabian Sea Region (Eds P. Clift, D. Kroon, C. Gaedicke and J. Craig), Geological Society of London, Special Publication, 195, 25-36. 
Garfunkel, Z. , Ben-Avraham, Z., 2001. Basins along the Dead Sea transform, in Peri-Tethys Memoir 6: Peri-Tethyan Rift/Wrench Basins and Passive Margins, edited by P.A. Ziegler, W. Cavazza, A.H.F. Robertson, and S. Crasquin-Soleau, Mémoires Museum National d'Histoire Naturelle de Paris, 186, 607-627.

Hatzfeld, D., Molnar, P., 2010. Comparisons of the kinematics and deep structures of the Zagros and Himalaya and of the Iranian and Tibetan plateaus and geodynamic implications. Review of Geophysics 48, RG2005, doi:10.1029/2009RG000304.

Henstock, T. J., Minshull, T. A., 2004. Localized rifting at Chagos bank in the India-Capricorn plate boundary zone. Geology 32, 237-240.

Huang, Y., Clemens, S. C., Liu, W., Wang, L., Prell, W. L., 2007. Large-scale hydrological change drove the Late Miocene C4 plant expansion in the Himalayan foreland and Arabian Peninsula. Geology 35, 531-534.

Iaffaldano, G., Husson, L., Bunge , H.P., 2011. Monsoon speeds up Indian plate motion, Earth and Planetary Science Letters 304, 503-510, doi:10.1016/j.eps1.2011.02.026.

Jolivet, L., et al., 2013. Aegean tectonics: strain localisation, slab tearing and trench retreat. Tectonophysics 597-598, 1-33, doi:10.1016/j.tecto.2012.06.011

Kashai, E. L., Croker, P. F., 1987. Structural geometry and evolution of the Dead Sea-Jordan rift system as deduced from new subsurface data. Tectonophysics 141, 33-60.

Kolla, V., Coumes, F., 1987. Morphology, internal structure, seismic stratigraphy, and sedimentation of Indus Fan, The American Association of Petroleum Geologists Bulletin, pp. 650-677

Krishna, K. S., Bull, J. M., Scrutton, R. A., 2009. Early (pre-8 Ma) fault activity and temporal strain accumulation in the central Indian Ocean. Geology 37, 227-230, doi: 10.1130/G25265A.1

Laigle, M., Hirn, A., Sachpazi, M., Roussos, N., 2000. North Aegean crustal deformation: an active fault imaged to $10 \mathrm{~km}$ depth by reflection seismic data.

Lazar, M., Ben-Avraham, Z., Schattner, U., 2006. Formation of sequential basins along a strike-slip fault - geophysical observations from the Dead Sea basin. Tectonophysics 421, 53-69. 
Le Pourhiet, L., Huet, B., May, D. A., Labrousse, L., Jolivet, L., 2012. Kinematic interpretation of the 3D shapes of metamorphic core complexes. Geochemistry, Geophysics, Geosystems, 13, Q09002, doi:10.1029/2012GC004271

Malavieille, J., 2010. Impact of erosion, sedimentation, and structural heritage on the structure and kinematics of orogenic wedges : analog models and case studies. GSA Today 20, 4-10, doi: 10.1130/GSATG48A.1

Mann, P., 2007. Global catalogue, classification and tectonic origins of restraining- and releasing bends on active and ancient strike-slip fault systems. Geological Society Special Publications 290, 13-142.

McCall, G.J.H., 1997. The geotectonic history of the Makran and adjacent areas of southern Iran. Journal of Asian Earth Science 15, 517-531.

McKenzie, D. P., Sclater, J. G., 1971. The evolution of the Indian Ocean since the Late Cretaceous, Geophysical Journal of Royal Astronomy Society 25, 437-528.

McNeill, L. C., Mille, A., Minshull, T. A., Bull, J. M., Kenyon, N. H., 2004. Extension of the North Anatolian Fault into the North Aegean Trough: Evidence for transtension, strain partitioning, and analogues for Sea of Marmara basin models. Tectonics 23, TC2016, doi:10.1029/2002TC001490

Merkouriev, S., DeMets, C., 2006.Constraints on Indian plate motion since 20 Ma from dense Russian magnetic data: Implications for Indian plate dynamics. Geochemistry, Geophysics, Geosystems 7 , Q02002, doi:10.1029/2005GC001079.

Minshull, T. A., White, R. S., Barton, P. J., Collier, J. S., 1992. Deformation at plate boundaries around the Gulf of Oman, Mar. Geol., 104, 265-277, doi:10.1016/0025-3227(92)90101-M.

Molnar, P., England, P., Martinod, J., 1993. Mantle dynamics, uplift of the Tibetan Plateau, and the Indian monsoon. Rev. Geophys. 31, 357-396.

Molnar, P., Stock, J., 2009. Slowing of India's convergence with Eurasia since 20 Ma and its implications for Tibetan mantle dynamics. Tectonics, 28, TC3001, doi:10.1029/2008TC002271 
Morley, C. K., 2013. Discussion of tectonic models for Cenozoic strike-slip fault-affected continental margins of mainland SE Asia. J. Asian Earth Sci., 76, 137-151, dx.doi.org/10.1016/j.jseaes.2012.10.019

Mouchot, N., 2009. Tectonique et sédimentation sur le complexe de subduction du Makran pakistanais. PhD thesis, 364 pp., Univ. Cergy-Pontoise, France.

Mouchot, N, Lallemant, S., Loncke, L., Leturmy, P., Mahieux, G., Chanier, F., Ellouz-Zimmermann, N., 2008. Vertical movements and recent sedimentary processes on the Makran accretionary prism off Pakistan, EGU General Assembly, Vienna.

Mouchot, N, Loncke, L., Mahieux, G., Bourget, J., Lallemant, S., Ellouz-Zimmermann, N., Leturmy, P., 2010. Recent sedimentary processes along the Makran trench (Makran active margin, off Pakistan), Marine Geology, 271, 17-31.

Mountain, G. S., Prell, W.L. 1990. A multiphase plate tectonic history of the southeast continental margin of Oman. In: Robertson, A. H. F., Searle, M. P. and Ries, A. C. (eds) the Geology and Tectonics of the Oman Region, Geological Society of London Special Publications, 49, 725-743.

Mouthereau, F., Lacombe, O., Vergés, J., 2012. Building the Zagros collisional orogen: Timing, strain distribution and the dynamics of Arabia/Eurasia plate convergence. Tectonophysics 532-535, $27-$ 60.

Mulder, T., Ducassou, E., Gillet, H., Hanquiez, V., Tournadour, E., Combes, J., Eberli, G. P., Kindler, P., Gonthier, E., Conesa, G., Robin, C., Sianipar, R., Reijmer, J.J.G., François, A., 2012. Canyon morphology on a modern carbonate slope of the Bahamas : evidence of regional tectonic tilting. Geology 40, 771-774, doi: 10.1130/G33327.1

Papanikolaou, D., Alexandri, M., Nomikou, P., Ballas, D., 2002. Morphotectonic structure of the western part of the North Aegean Basin based on swath bathymetry. Marine Geology 190, 465492.

Pubellier, M., Rangin, C., Ego, F. et al. 2005. Atlas of the margins of SE Asia, $N^{\circ} 176,176$ maps, 174 chap., 171 CDRom, Geol. Soc. France-Amer. Assoc. Petrol. Geologists. 
Quittmeyer R. C., Kafka, A. L., 1984. Constraints on plate motions in southern Pakistan and the northern Arabian Sea from the focal mechanisms of small earthquakes. Journal of Geophysical Research 89, 2444-2458.

Reading, H.G., Richards, M., 1994. Turbidites systems in deep-water basin margins classified by grain size and feeder system. American Association of Petroleum Geology Bulletin, 792-822.

Rodriguez, M., Fournier, M., Chamot-Rooke, N., Huchon, P., Bourget, J., Sorbier, M., Zaragosi, S., Rabaute, A., 2011. Neotectonics of the Owen Fracture Zone (NW Indian Ocean): structural evolution of an oceanic strike-slip plate boundary (2011). Geochemistry, Geophysics, Geosystems 12, Q12006 http://dx.doi.org/10.1029/2011GC003731.

Rodriguez, M., Fournier, M., Chamot-Rooke, N., Huchon, P., Zaragosi, S., Rabaute, A., 2012. Mass wasting processes along the Owen Ridge (Northwest Indian Ocean), Marine Geology 326-328, 80100, 10.1016/j.margeo.2012.08.008

Rodriguez, M., Chamot-Rooke, N., Hébert, H., Fournier, M., Huchon, P. 2013a. Owen Ridge deepwater submarine landslides: Implications for tsunami hazard along the Oman coast, NHESS, 13, 417-424.

Rodriguez, M., Chamot-Rooke, N., Fournier, M., Huchon, P., Delescluse, M., 2013b. Mode of opening of an oceanic pull-apart: The $20^{\circ} \mathrm{N}$ Basin along the Owen Fracture Zone (NW Indian Ocean), Tectonics 32, 1-15, doi:10.1002/tect.20083

Rodriguez, M., Chamot-Rooke, N., Huchon, P., Fournier, M., Delescluse, M., 2014. The Owen Ridge uplift in the Arabian Sea: implications for the sedimentary record of Indian monsoon in Late Miocene, Earth and Planetary Science Letters 394, 1-12, doi : 10.1016/j.eps1.2014.03.011

Ross, D. A., Uchupi, E., White, R., 1986. The geology of the Persian-Gulf of Oman Region : a synthesis. Reviews of Geophysics 24, 537-556.

Royer, J. Y., Chaubey, A. K., Dyment, J., Bhattacharya, G. C., Srinivas, K., Yateesh, V., Ramprasad, T., 2002.Paelogene plate tectonic evolution of the Arabian and Eastern Somali basins. in The Tectonic and Climatic Evolution of the Arabian Sea Region, edited by P. D. Clift et al., Geological Society Special Publications 195, 7-23 
Schattner, U., 2010. What triggered the early-to-mid Pleistocene tectonic transition across the entire Eastern Mediterranean? Earth and Planetary Science Letters 289, 539-548.

Schlische, R. W., Withjack M. O., Eisenstadt, G., 2002.An experimental study of the secondary deformation produced by oblique slip normal faulting. American Association of Petroleum Geology Bulletin 86, 885-906.

Schlüter, H. U., Prexl, A., Gaedicke, C., Roeser, H., Reichert, C., Meyer, H., von Daniels C., 2002.The Makranaccretionary wedge: sediment thicknesses and ages and the origin of mud volcanoes. Marine geology 185, 219-232

Schulz, H., von Rad, U., Erlenkeuser, H., 1998. Correlation between Arabian Sea and Greenland climate oscillations of the past 110000 years. Nature, 393, 54-57.

Shipboard Scientific Party,1989.Site 731. In Prell, W.L., Niitsuma, N., et al., Proc. ODP, Init.Repts., 117: College Station, TX (Ocean Drilling Program), 585-652.

Skinner, L.C. and McCave, I.N., 2003. Analysis and modelling of gravity- and piston coring based on soil mechanics. Marine Geology 199, 181-204.

Smit J., Brun J. P, Cloetingh, S., Ben-Avraham, Z., 2008.Pull-apart basin formation and development in narrow transform zones with application to the Dead Sea Basin. Tectonics 27, TC6018, doi:10.1029/2007TC002119

Smit, J., Brun, J-P., Cloething, S., Ben-Avraham, Z., 2009. The rift-like structure and asymmetry of the Dead Sea Fault. Earth and Planetary Science Letters 290, 74-82, doi:10.1016/j.eps1.2009.11.060

Smit J., Burg J-P, Dolati A., Sokoutis D., 2010. Effects of mass waste events on thrust wedges: analogue experiments and application to the Makran accretionary wedge. Tectonics 29: TC3003

Smith, G., McNeill, L. Henstock, T. J., Bull, J., 2012. The structure and fault activity of the Makran accretionary prism. Journal of Geophysical Research 117, B07407, doi:10.1029/2012JB009312.

Smith, G. L., McNeill, L. C., Wang, K. He, J., Henstock, T.J., 2013. Thermal structure and megathrust seismogenic potential of the Makran subduction zone. Geophysical Research Letters 40, 15281533, doi:10.1002/grl.50374. 
ten Brink, U. S., Flores, C. H., 2012. Geometry and subsidence history of the Dead Sea basin: A case for fluid induced mid-crustal shear zone? Journal of Geophysical Research 117, B01406, doi:10.1029/2011JB008711.

Wakabayashi, J., 2007. Stepovers that migrate with respect to affected deposits: field characteristics and speculation on some details of their evolution, in Tectonics of Strike-Slip Restraining and Releasing Bends, edited by W.D. Cunningham and Paul Mann, Geol. Soc. Spec. Publ, 290, 169188.

Wang, P., Steven Clemens, S., Beaufort, L., Braconnot, P., Ganssene, G., Jiana, Z., Kershawf, P., Sarntheing, M., 2005. Evolution and variability of the Asian monsoon system: state of the art and outstanding issues. Quaternary Sci. Rev. 24, 595-629.

Weissel, J. K., Anderson, R. N., Geller, C. A., 1980. Deformation of the Indo-Australian plate. Nature $287,284-291$.

Whipple, K. X., 2009. The influence of climate on the tectonic evolution of mountain belts. Nature geoscience 2, 97-104, doi:10.1038/ngeo413

White, R. S., Klitgord, K., 1976. Sediment deformation and plate tectonics in the Gulf of Oman. Earth and Planetary Science Letters 32, 199-209.

Whitmarsh, R.B., Weser, O. E., Ross, D. A., 1974. Initial report DSDP, U.S. Government Printing Office, Washington, D.C., v. 23, p. 1180.

Whitmarsh, R.B., 1979. The Owen Basin off the south-east margin of Arabia and the evolution of the Owen Fracture Zone. Geophysical Journal of the Royal Astronomical Society 58, 441-470.

Wiens, D. A., Demets, C., Gordon, R. G., Stein, S., Argus, D., Engeln, J. F., Lundgren, P., Quible, D., Stein, C., Weinstein, S., Woods, D. F., 1985. A diffuse plate boundary model for Indian ocean tectonics. Geophysical Research Letters 12, 429-432.

Wu, J. E., McClay, K., Whitehouse, P., Dooley, T., 2009.4D analogue modelling of transtensional pull-apart basins. Marine and Petroleum Geology 26, 1608-1623.

Ziegler, M., Lourens, L. J., Tuenter, E., Hilgen, F., Reichart, G-J., Weber, N, 2010. Precession phasing offset between Indian summer monsoon and Arabian Sea productivity 
linked to changes in Atlantic overturning circulation. Paleoceanography 25, PA3213 doi:10.1029/2009PA001884.

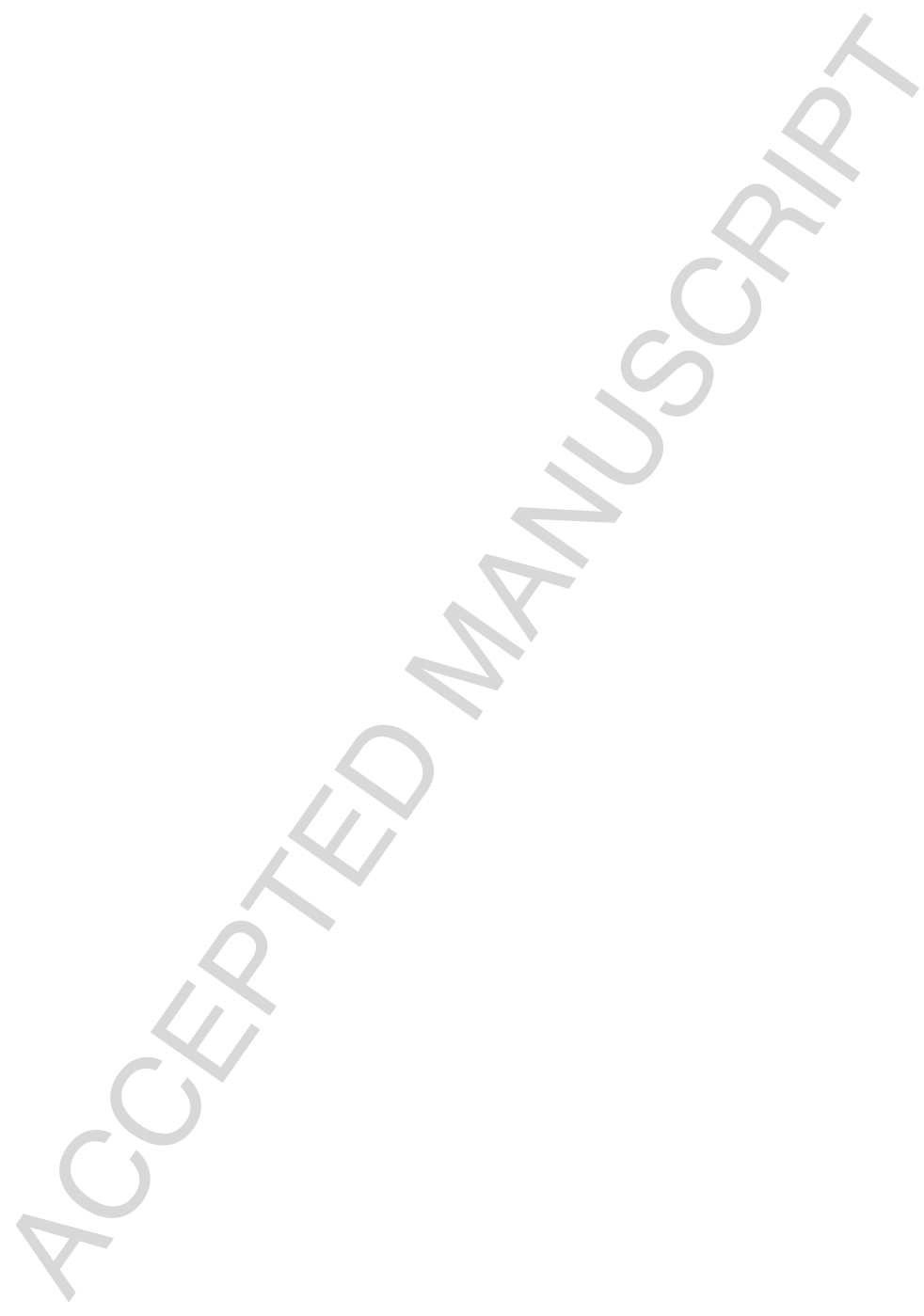




\section{ACCEPTED MANUSCRIPT}

\begin{tabular}{|c|c|c|c|c|}
\cline { 2 - 5 } \multicolumn{1}{c|}{} & \multicolumn{3}{c|}{ Sedimentation rates range along the Owen-Murray Ridge } \\
\cline { 2 - 5 } \multicolumn{1}{c|}{} & \multicolumn{2}{c|}{ Owen Ridge } & \multicolumn{2}{c|}{ Murray Ridge } \\
\hline CORES & $\begin{array}{c}\text { ODP 722 } \\
\text { (Shipboard Scientific } \\
\text { Party, 1989) }\end{array}$ & $\begin{array}{c}\text { KS07 } \\
\text { (Bourget et al., } \\
2013)\end{array}$ & $\begin{array}{c}\text { MD-2881 } \\
\text { (Ziegker et al., 2007) }\end{array}$ & $\begin{array}{c}\text { S090-93KL } \\
\text { (Schultz et al., 1998) }\end{array}$ \\
\hline Time sampled & $15 \mathrm{Ma}$ & $160 \mathrm{ka}$ & $750 \mathrm{ka}$ & $110 \mathrm{ka}$ \\
\hline $\begin{array}{c}\text { Average } \\
\text { sedimentation rates } \\
\text { (Plio-Pleistocene } \\
\text { rates) }\end{array}$ & $30 \mathrm{~m} / \mathrm{Ma}-46 \mathrm{~m} / \mathrm{Ma}$ & $54 \mathrm{~m} / \mathrm{Ma}$ & $40 \mathrm{~m} / \mathrm{Ma}$ & $55 \mathrm{~m} / \mathrm{Ma}$ \\
\hline
\end{tabular}

Table 1a

\begin{tabular}{|c|c|c|}
\hline & TWT (ms) & Age estimates (Myr) \\
& & \\
\hline $\begin{array}{c}\text { Thickness of } \\
\text { pelagic } \\
\text { deposits } \\
\text { overlying the } \\
\text { last active } \\
\text { CLS -B } \\
\text { (OFZ- }\end{array}$ & $\mathbf{1 8 0} \pm \mathbf{1 0}$ & $\mathbf{3 . 5} \pm \mathbf{1 . 4}$ \\
Dalrymple \\
connection)
\end{tabular}

Table $1 b$ 

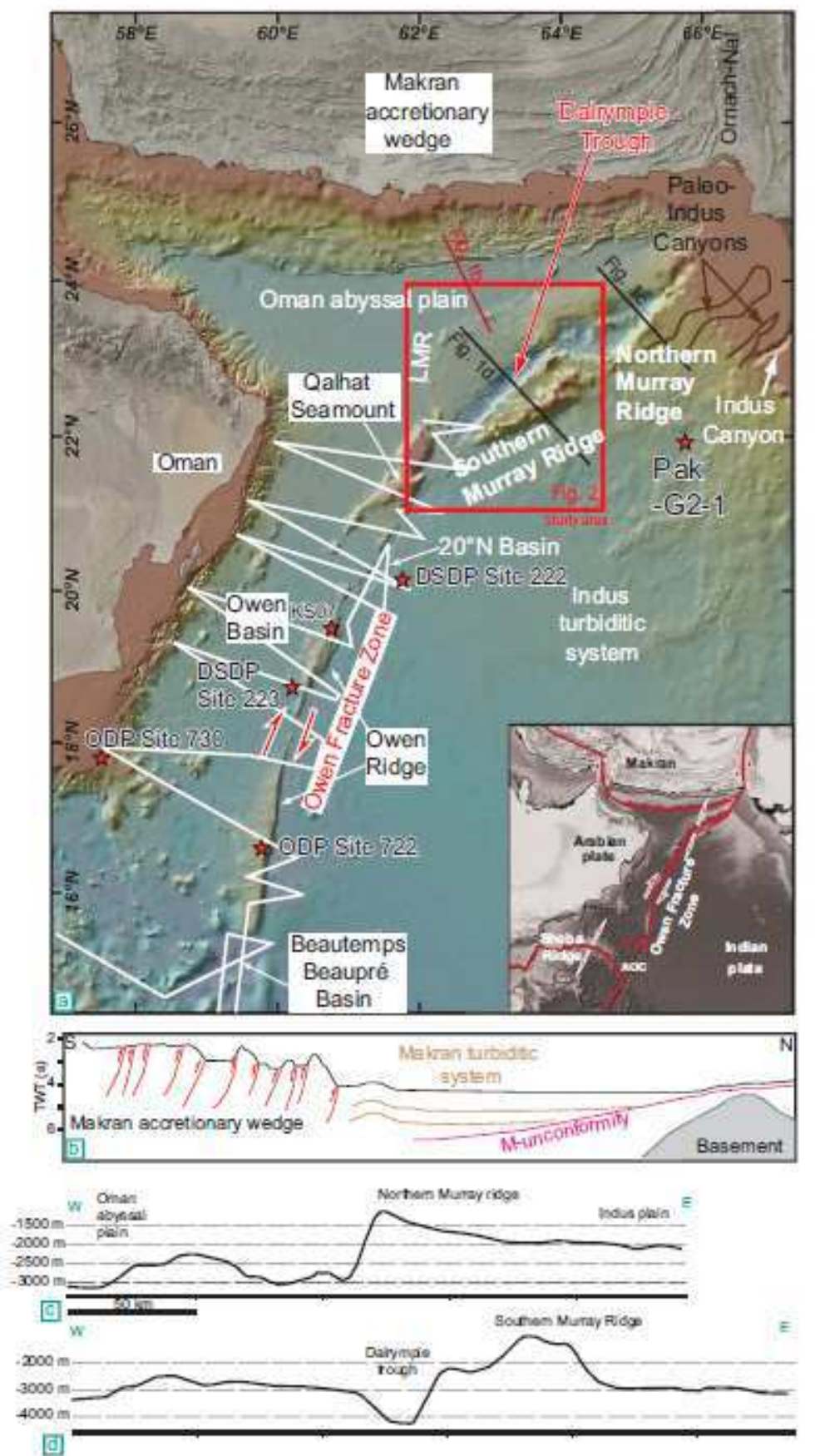

Figure 1 


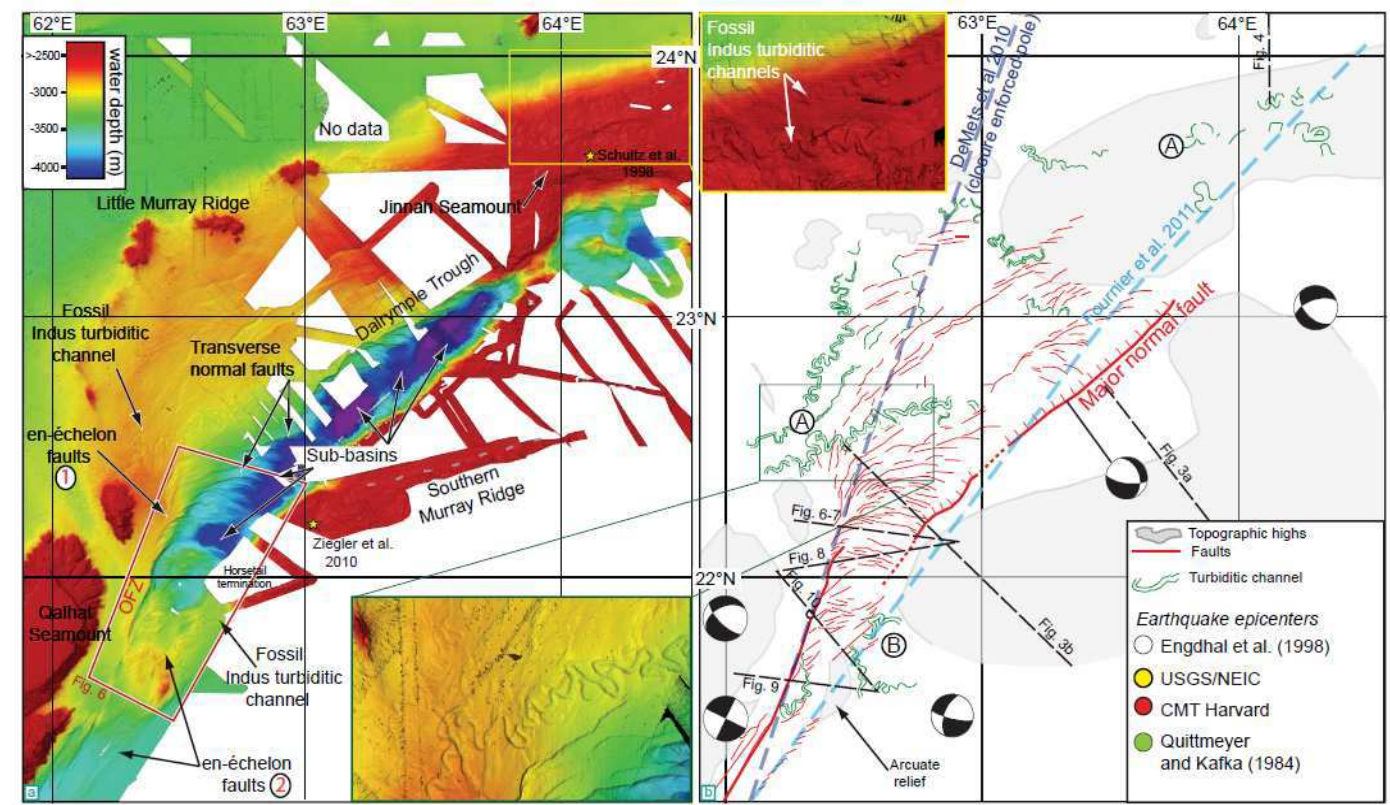

Figure 2 

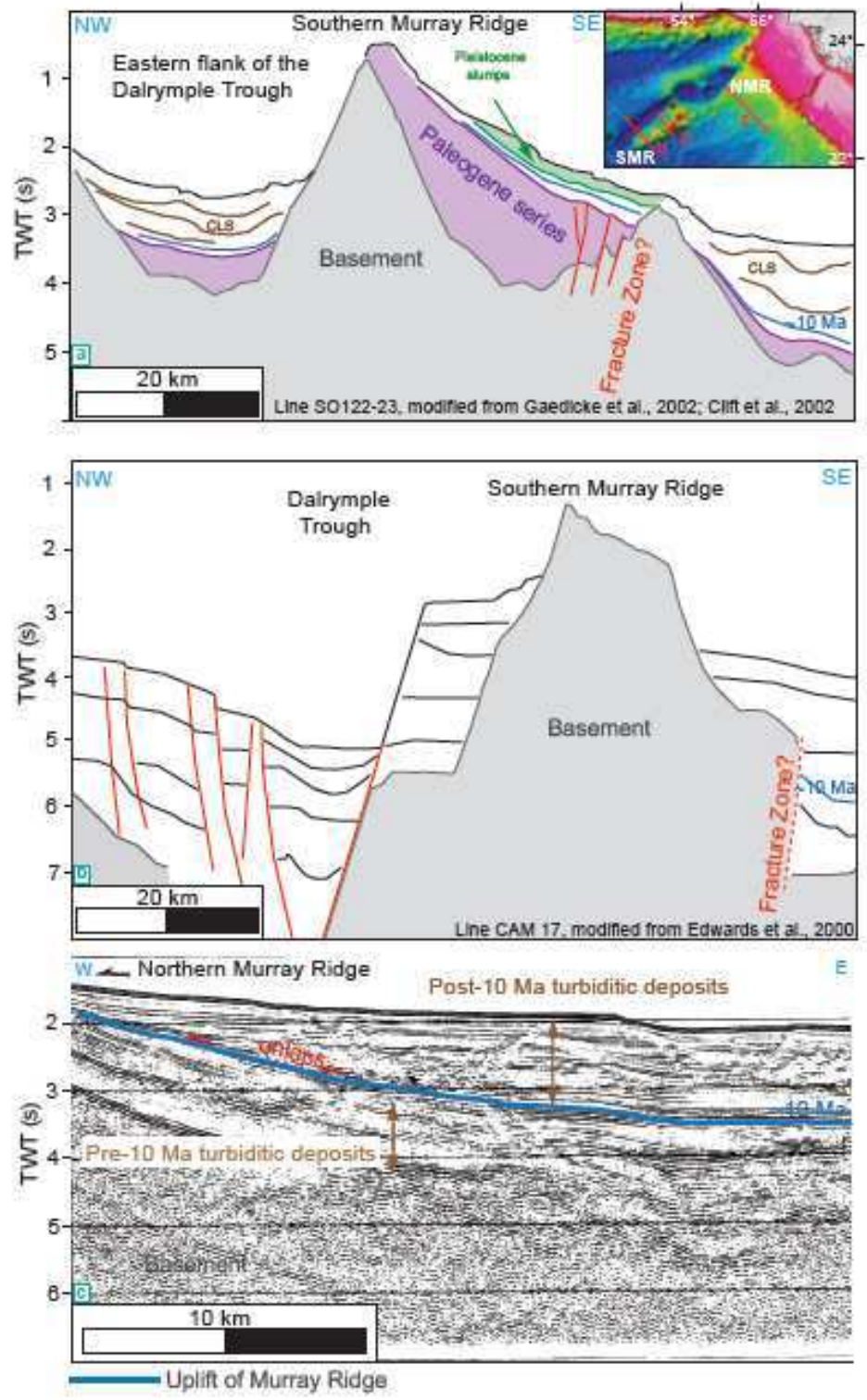

Figure 3 


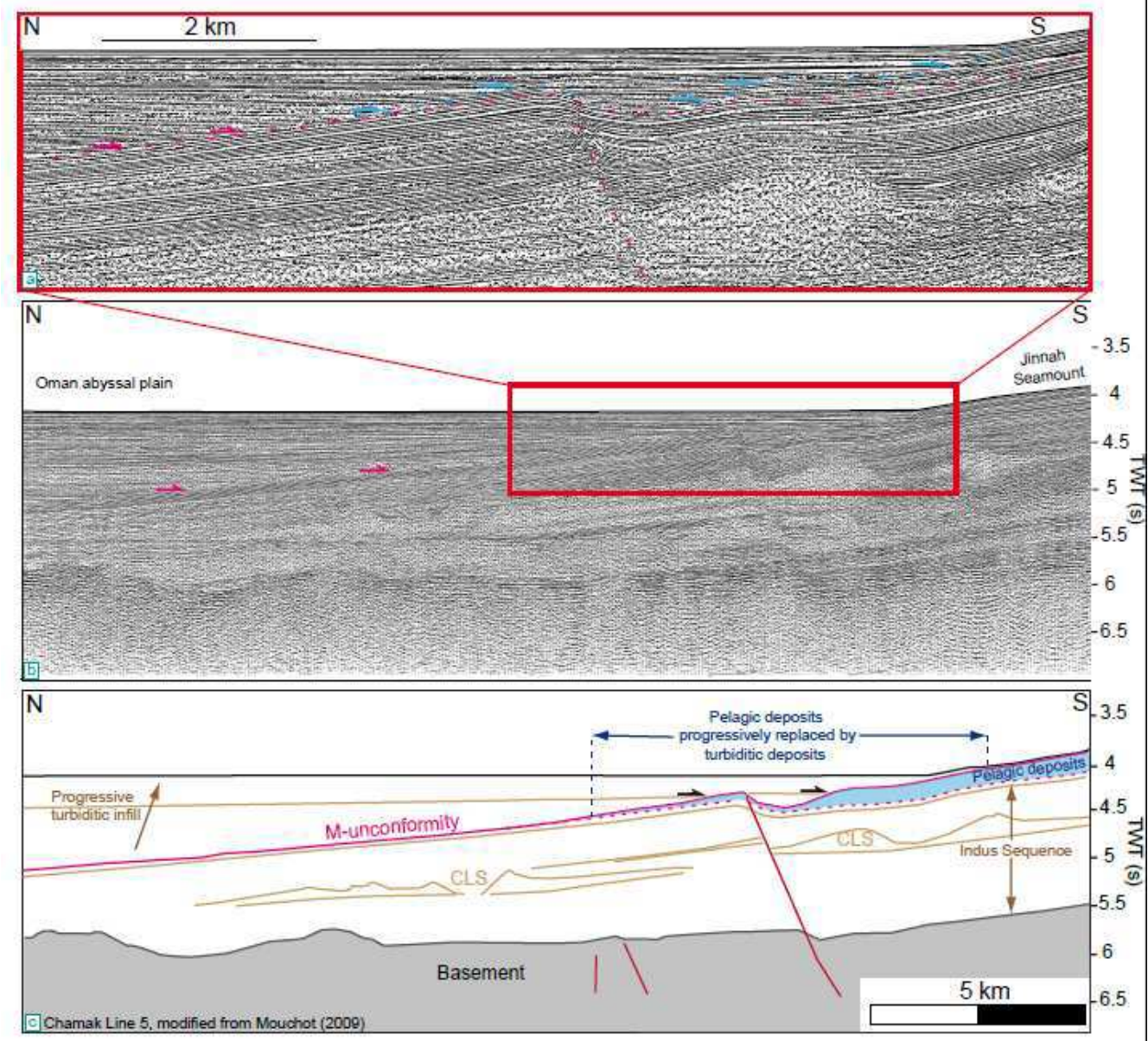

Figure 4 


\begin{tabular}{|c|c|c|}
\hline Sedimentary feature & Seismic facies & Description \\
\hline \multirow{3}{*}{$\begin{array}{c}\text { Turbiditic } \\
\text { channel-levee } \\
\text { system }\end{array}$} & 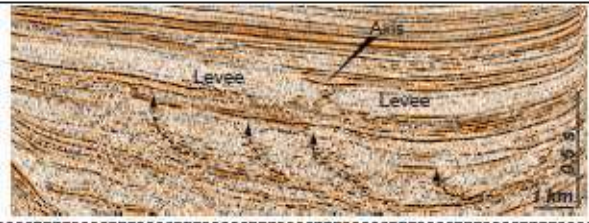 & $\begin{array}{l}\text { - Channel axes are characterized by lens-like } \\
\text { architecture with high-amplitude reflection } \\
\text { - Levees display a wedge shape } \\
\text { (lateral thickness variations). } \\
\text { high amplitude transparent facies } \\
\text { - Channel axes migrate during their life-time }\end{array}$ \\
\hline & 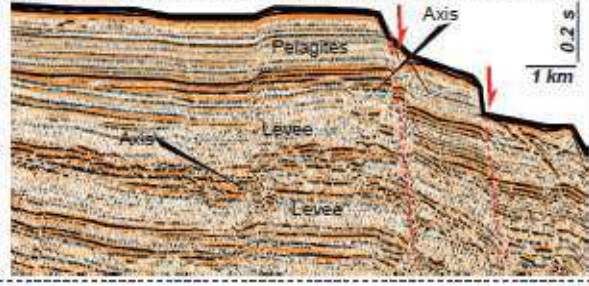 & - Example of a system of faults, which offsets \\
\hline & 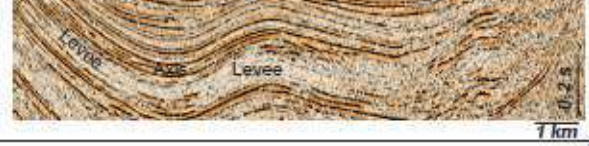 & - Folded turbiditic channel-levee systems \\
\hline Contourite deposits & Moat & $\begin{array}{l}\text { - Aggradation of deposits non parallel } \\
\text { to the accumulation surface } \\
\text { Sigmoid configuration of the sedimentary } \\
\text { - body (lateral thickness variations } \\
\text { and pinching of sedimentary layers) }\end{array}$ \\
\hline Mass transport deposits & 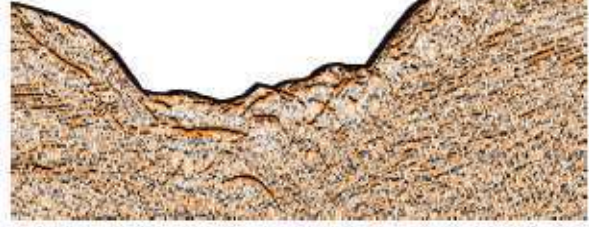 & $\begin{array}{l}\text { - Hyperbolic to chaotic reflections, } \\
\text { with a transparent seismic facies }\end{array}$ \\
\hline
\end{tabular}

Figure 5 

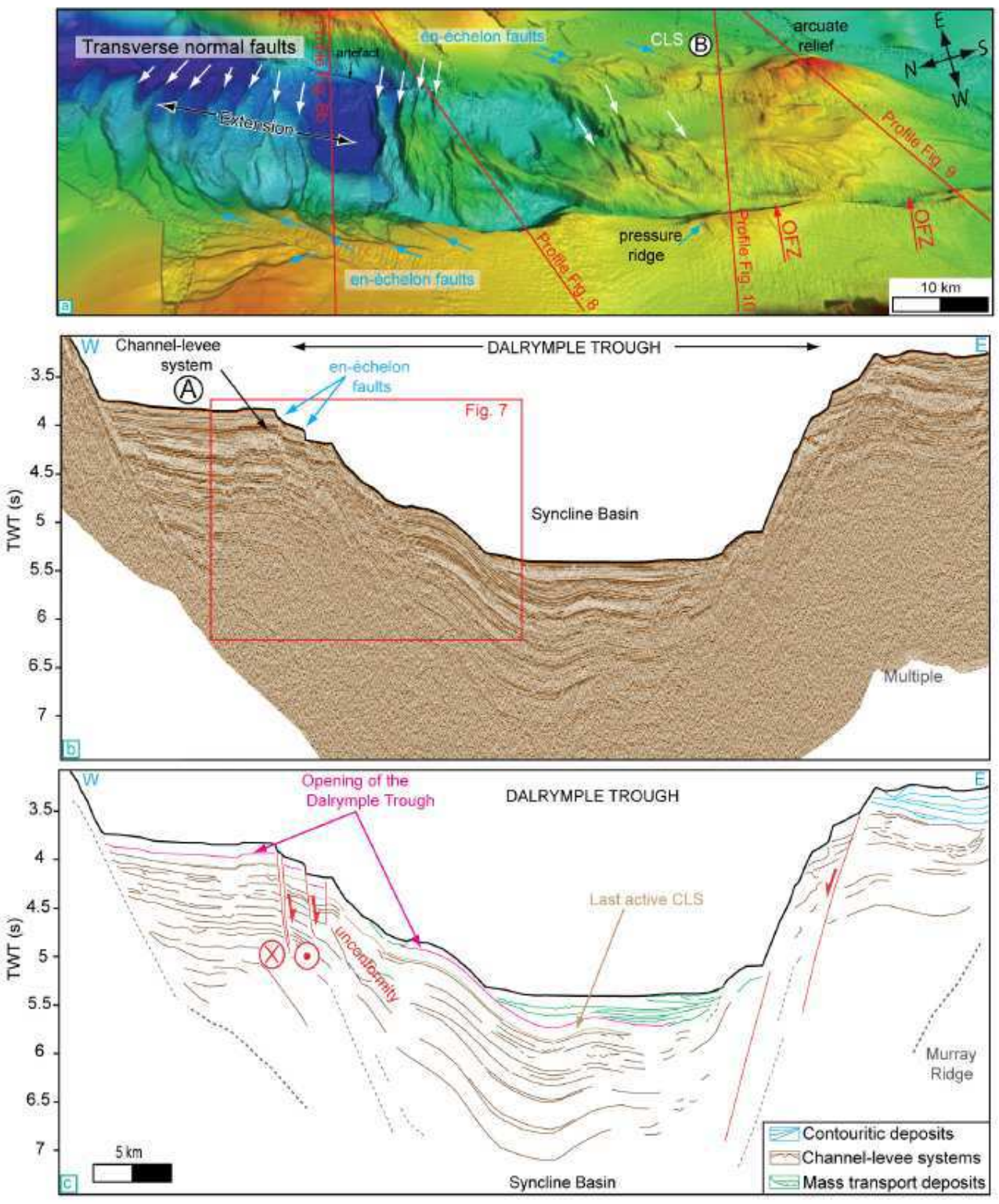

Figure 6 


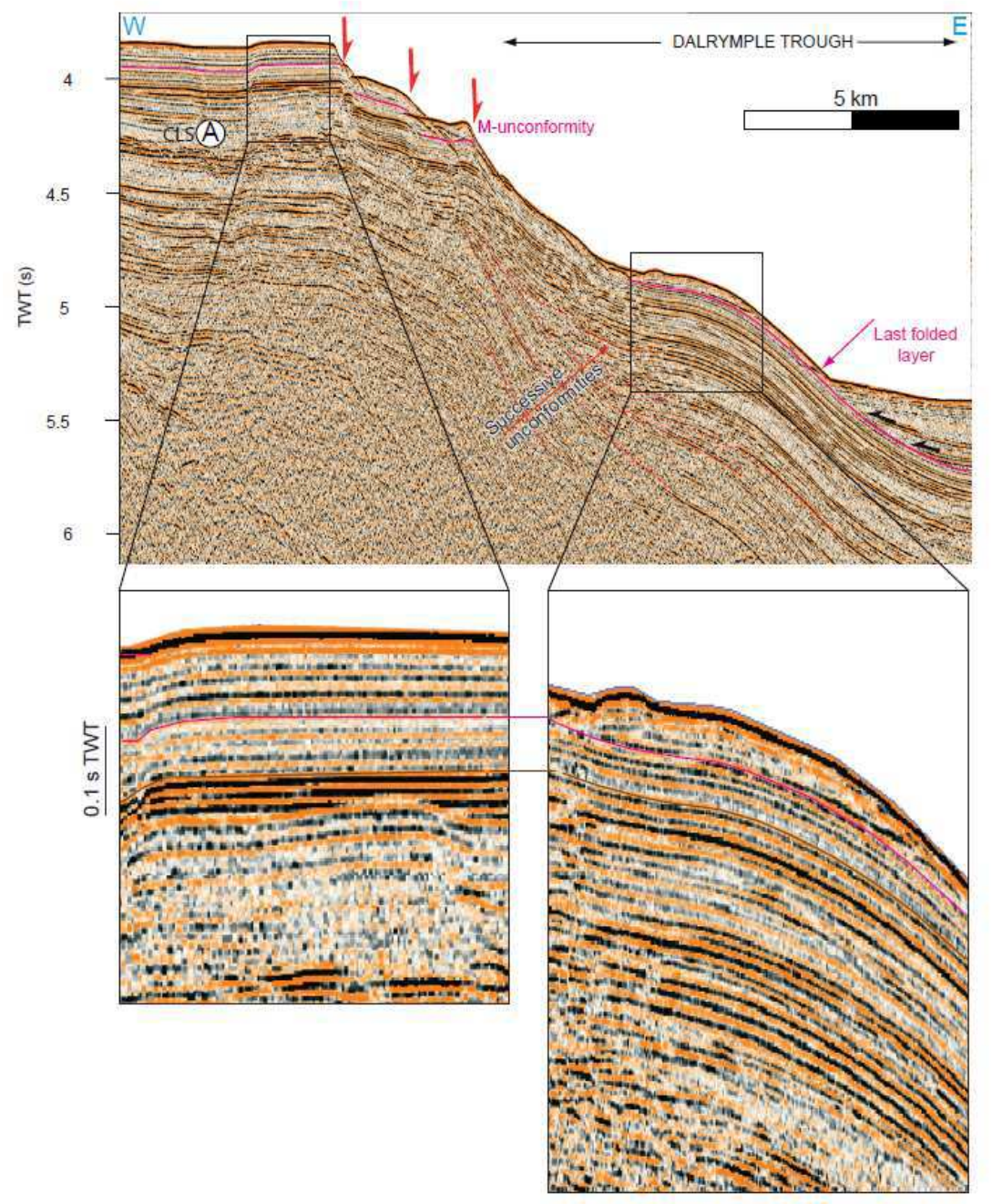

Figure 7 

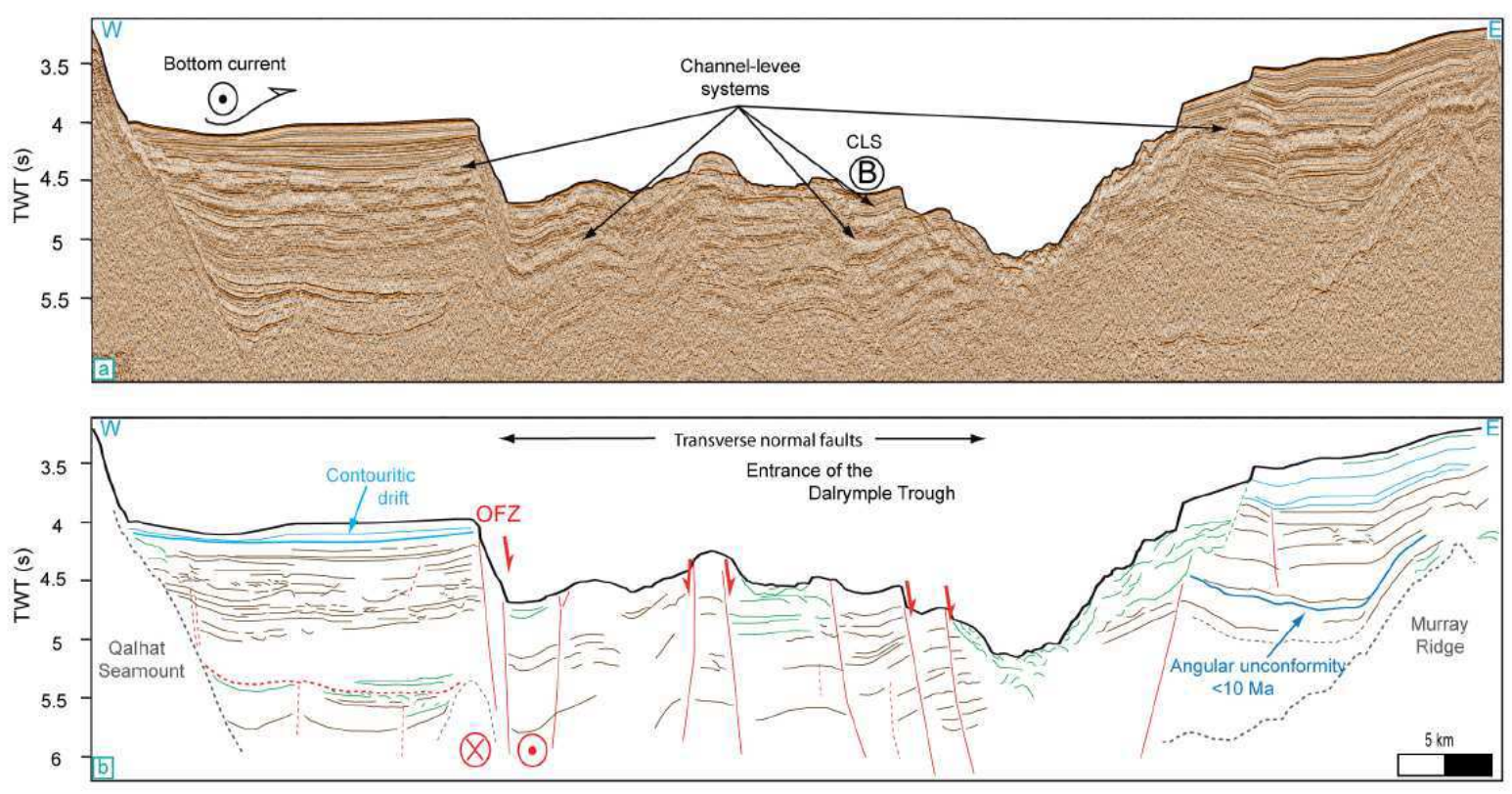

Figure 8 

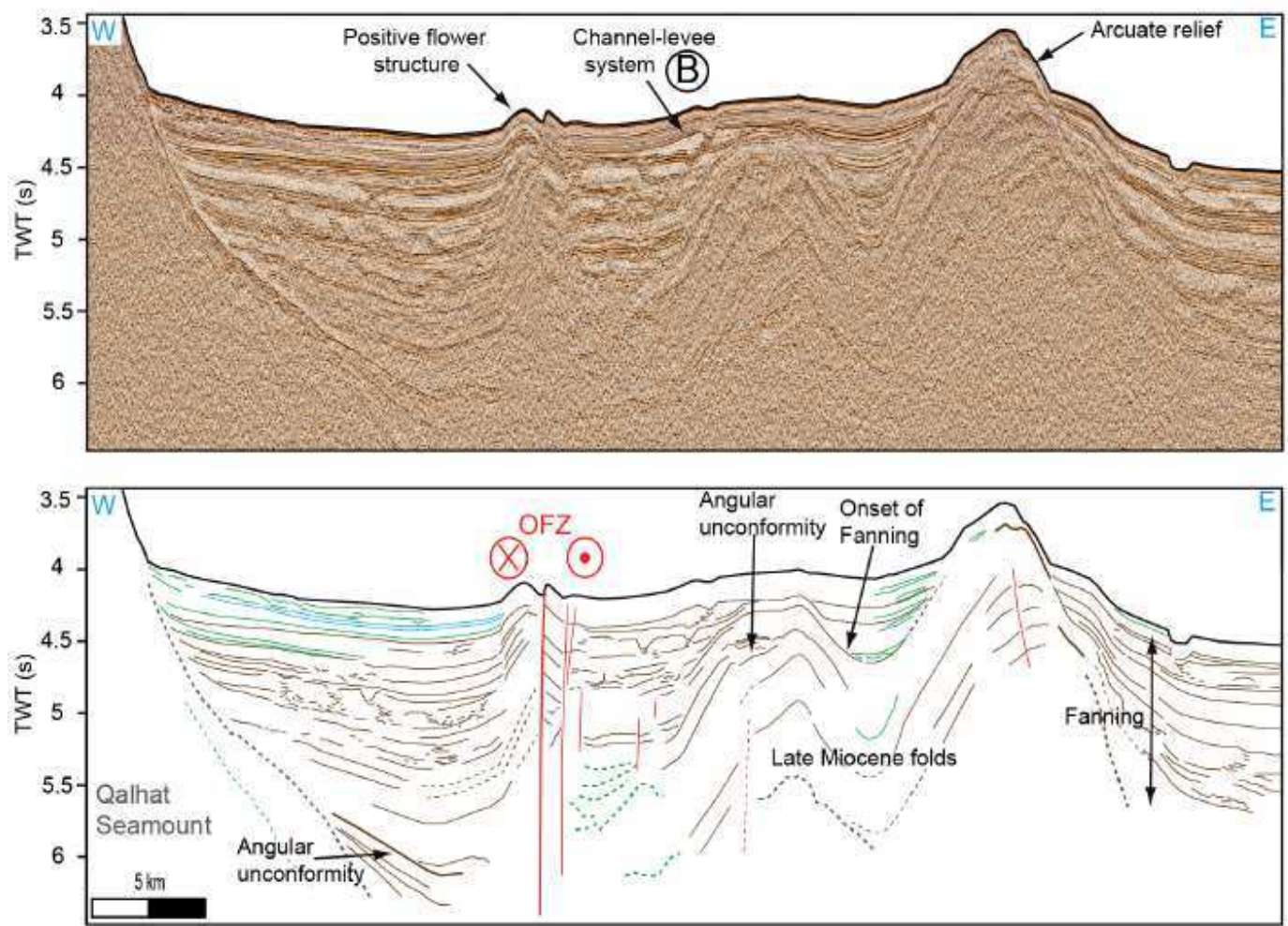

Figure 9 

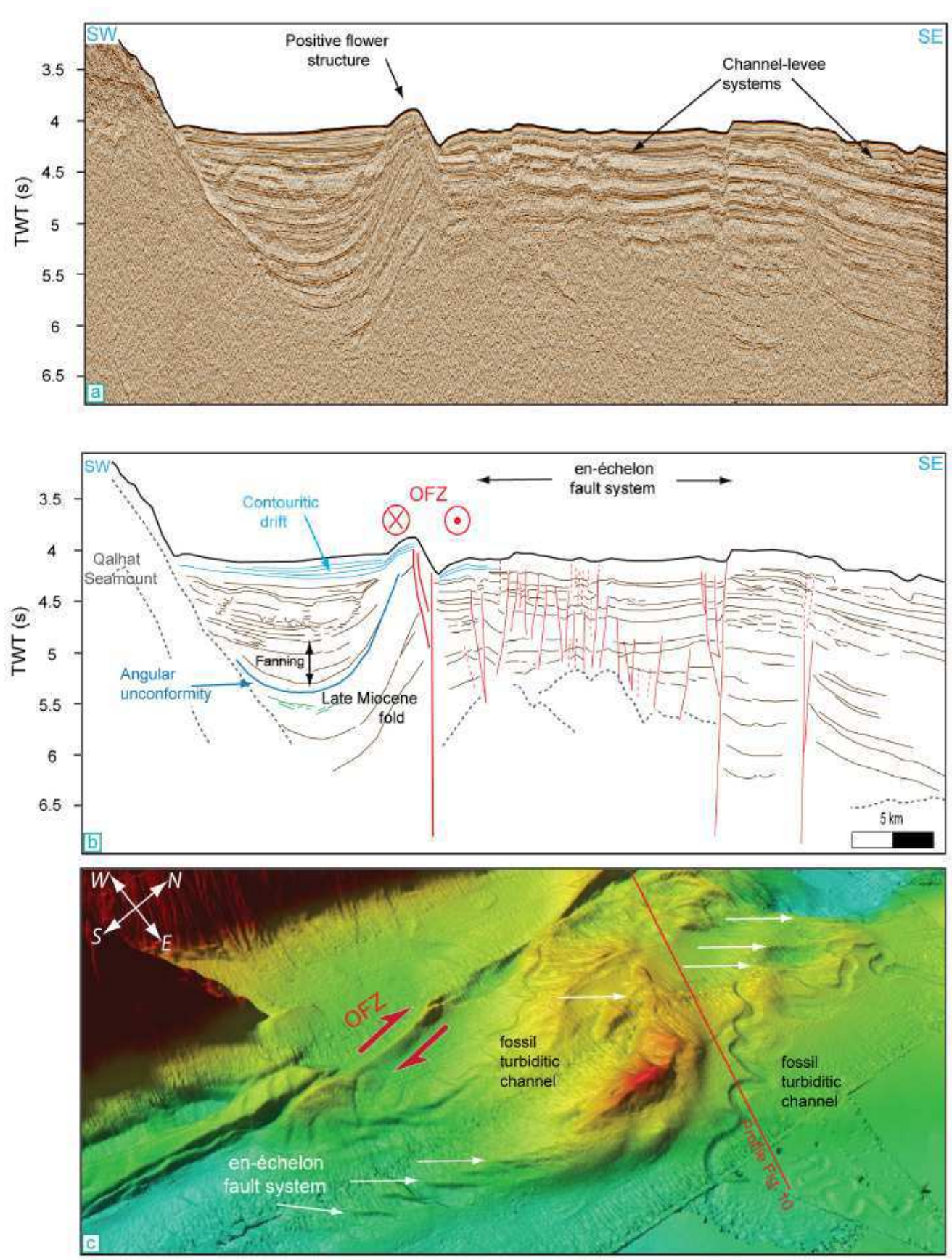

Figure 10 


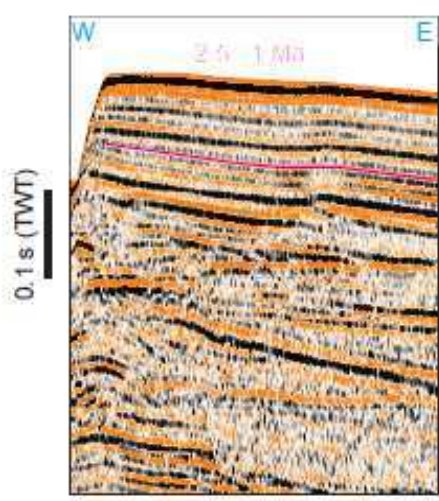

$20^{\circ} \mathrm{N}$ pull-apart basin (age estimate from DSDP Site 222 sedimentation rates)

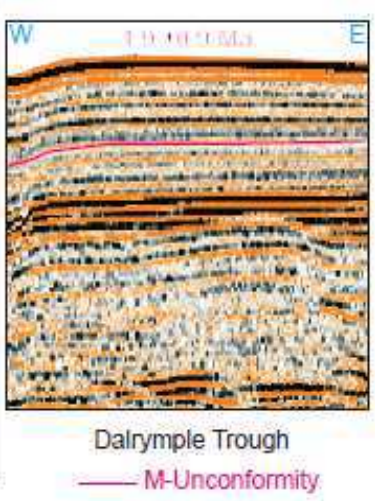

Figure 11

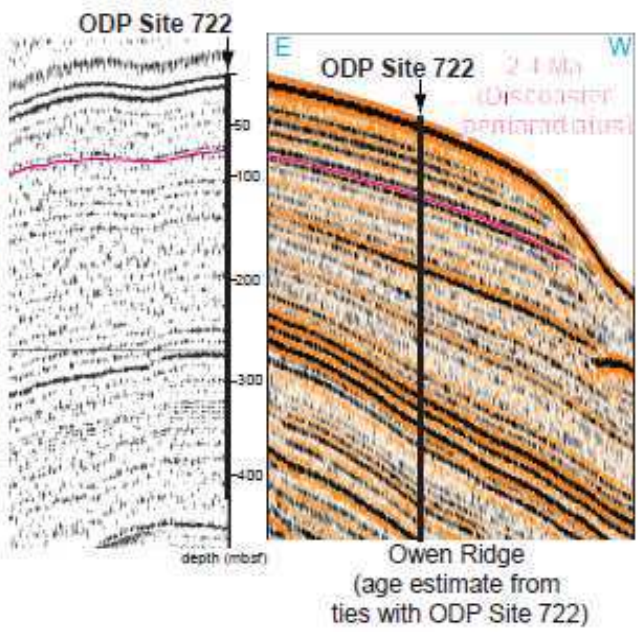



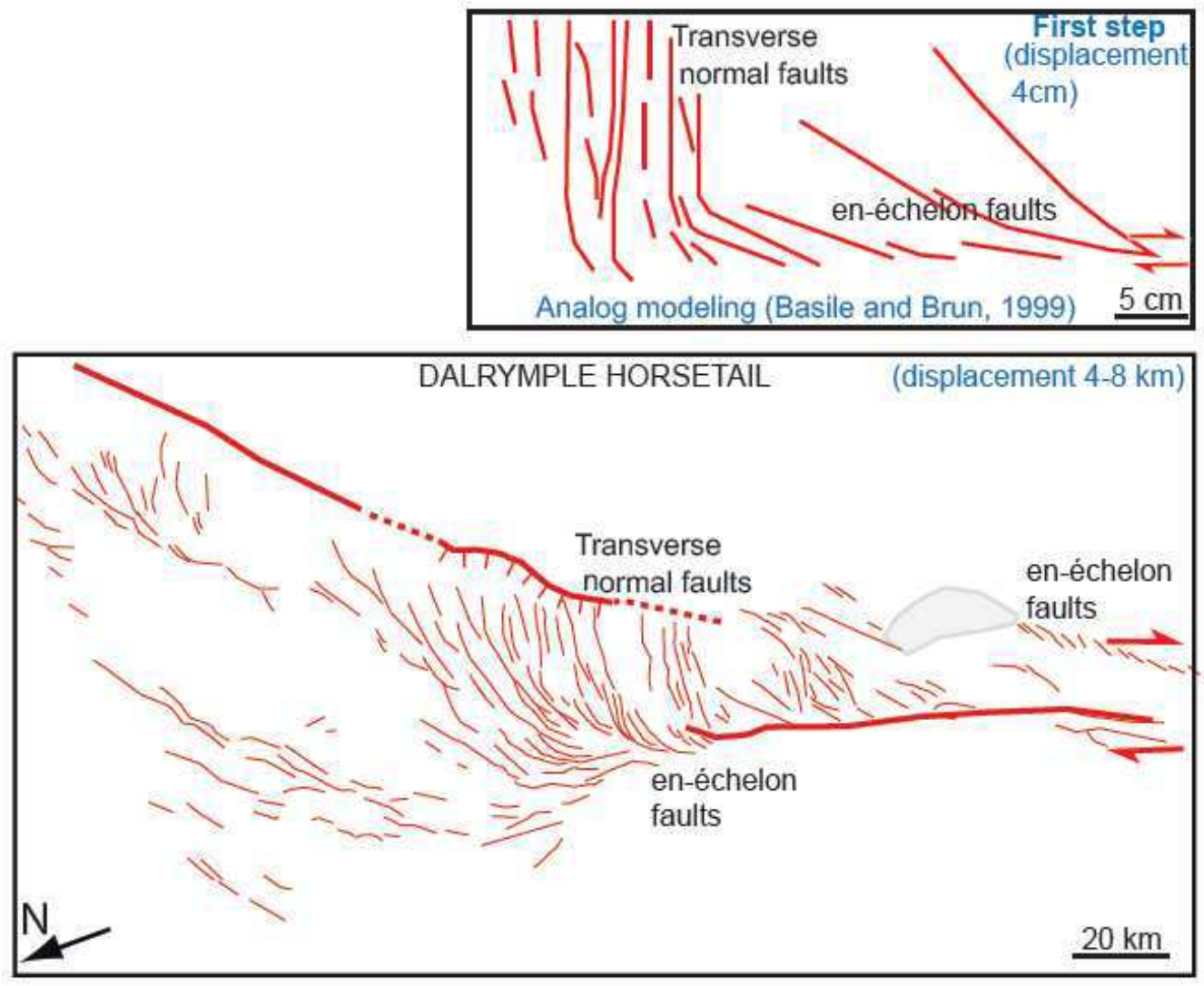

Figure 12 

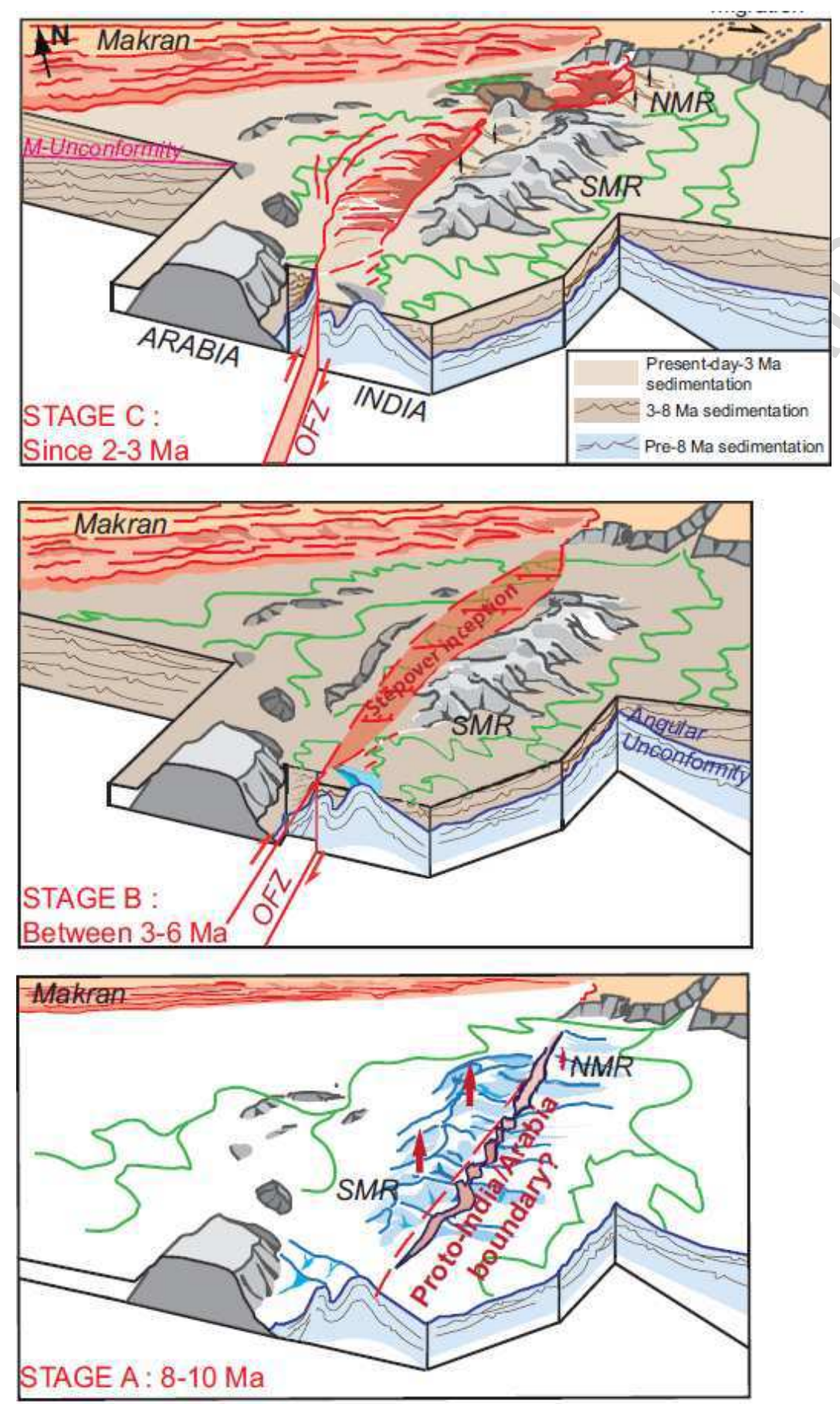

Figure 13 

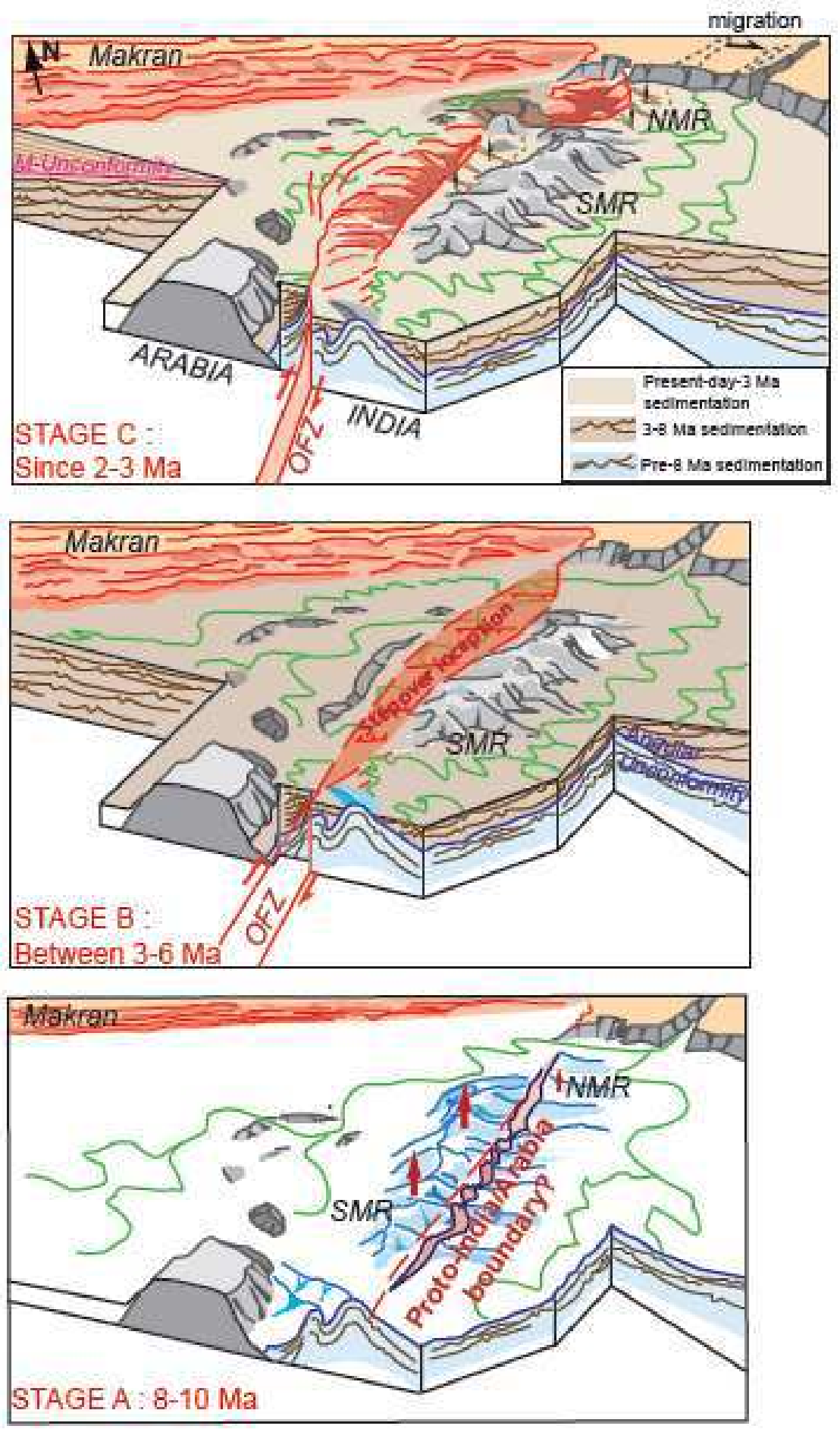

\section{Graphical abstract}


highlights

-A detailed structural framework of the Dalrymple horsetail termination of the Owen Fracture Zone -Opening of the Dalrymple Trough around $2 \mathrm{Ma}$ coeval with the regional M-unconformity -Episode of compressive deformation along the India-Arabia plate boundary at 8-10 Ma 